Article

\title{
Archaeometry's Role in Cultural Heritage Sustainability and Development
}

\author{
Ioannis Liritzis ${ }^{1,2, *}$ and Elena Korka ${ }^{3}$ \\ 1 Key Research Institute of Yellow River Civilization and Sustainable Development \& College of Environment \\ and Planning, Henan University, Kaifeng 475001, China \\ 2 Laboratory of Archaeometry, Department of Mediterranean Studies, University of the Aegean, 85100 \\ Rhodes, Greece \\ 3 Honorary G. D. of Antiquities and Cultural Heritage, Ministry of Culture and Sports, 11525 Athens, Greece; \\ ekorka@otene.gr \\ * Correspondence: liritzis@rhodes.aegean.gr or ioliritzis@gmail.com; Tel.: +30-6932-275757
}

Received: 27 January 2019; Accepted: 18 March 2019; Published: 3 April 2019

\begin{abstract}
The interdisciplinary field of archaeometry covers a wide range of subject categories and disciplines in relation to science and humanities. It is a well-established academic field of study and accredited part of higher education. Since its inception, the nomenclature designation of archaeometry signifies the appropriate methodology applied to archaeological materials and questions emerging from this field, regarding monuments, artifacts, and the reconstruction and management of landscape bearing cultural assets. The measurements of tangible culture denote significant information, such as chronology, authenticity, technology, characterization, provenance, discovering buried antiquities, ancient-day life activities, and three-dimensional (3D) reconstructions and modelling; furthermore, proxy data collected from environmental dynamic non-liner perturbations, which link local ecosystems with dwellings, are gathered by academia to study the past. The traditional rooting signifies the cultural legacies of people, which define the human desire and the confidence of memory and future trends. Beyond the mere study of the past, archaeometry's role increasingly proves affinity to prosperity, if properly managed. The major archaeometrical contributions in cultural heritage and archaeology in general are reviewed herein, and we present the policies that could develop archaeometrical data into a sustainable stage of local, regional, and national economic development. The United Nations Educational, Scientific, and Cultural Organization (UNESCO) conventions for the documentation and protection of cultural heritage via new technologies and archaeometry are reviewed and connected to development strategies and sustainable development goals.
\end{abstract}

Keywords: archaeological sciences; buried antiquities; prospection; documentation; digitalization; management; UNESCO; cultural tourism; economic values; new technologies; information

\section{Introduction}

\subsection{Cooperation between Scientific and Humanities Disciplines}

The relationship that links the interdisciplinary field of archaeometry with the concept of sustainability, as well as the way these two fields cooperate, alerted authorities and institutions of the public and private sector.

Archaeometry, or archaeological sciences, is the application of natural sciences to solving archaeological or cultural heritage problems. This interdisciplinary subject combines many disciplines such as physics, chemistry, geology, astronomy, mathematics, geophysics, geology, biology, informatics, etc. The main objective of the archaeological sciences is the comprehension of past societies through 
the study of natural sciences and new technologies of material culture [1,2]. By using the latest technological achievements in a combined and flexible manner, archaeometry is capable of detecting and extracting hidden information from heritage objects, which may comprise evidence that can determine the object's origin, construction period or technique, etc. The strategy consists of the use of technological achievements through areas of science, and the creation of innovative models, protocols, and web platforms, as well as, given direct or indirect options to legacy, the enhancement of cultural values and the creation of ecosystems and cultural heritage services. Hence, the cooperation between scientific and historic disciplines is now prevalent, only beginning in the 1960s, due to what seemed to be a lack of mutual understanding. This allowed bridging the gap between the fields of physics and chemistry on the one side and the needs and problems of archaeologists or historians on the other.

Archaeology today is an extremely diverse discipline, encompassing interest groups, which focus on distinct periods, regions, theoretical perspectives, and methodological techniques. Although this diversity is a positive development, bringing to light problematic issues due to miscommunication from different components of the discipline [3,4], or the development of epistemological arguments to coin progress perplex the archaeological-archaeometrical connection, and each new term is triggered by archaeological theorists and archaeological scientists [5,6].

At any rate, archaeometry applies a wide range of scientific techniques for the study of both heritage objects and historic/prehistoric events. Such techniques are based on basic principles and phenomena of physics (e.g., radioactivity, electricity and magnetism, atomic theory, electromagnetic radiation), chemistry (e.g., diffusion, reactions, melting, affinities), geology (e.g., geomorphology, sedimentology, petrology), geophysics (e.g., paleoclimate, geomagnetic field, atmosphere), astronomy (e.g., solar system, celestial mechanics), and mathematics (e.g., algorithms, statistics). The important contribution of archaeometry to cultural heritage and archaeology for most of the years of recent developments remained known either to a few open-minded archaeologists or to a narrow group of academia.

Eventually, understanding of the usefulness of cultural tourism and the valorization of cultural heritage assets, supported by United Nations Educational, Scientific, and Cultural Organization (UNESCO) and European Union (EU) projects placed archaeometry as one of the top priorities for sustainability on national and regional levels [7-9]. However, when overcoming the past theoretical approaches using archaeological dialogues, one should consider the perpetually accredited scientifically holistic approach involving theory and practice, covering processual and post-processual approaches for the ever-developing archaeology (PASHA). This approach was designed to account for new diversity and virtual reconstruction in the field, integrating micro and macro perspectives from human life stories (bio-archaeology, ancient a-DNA, and isotopes) to their larger social, cultural, and environmental framework (travels, interaction, networks, major genetic shifts, paleoclimates, and paleoenvironments). This, in turn, led to the introduction of new scientific branches emerging from science, technology, engineering, and mathematics (STEM), as well as the addition of arts (STEAM) $[10,11]$ and, more recently, the addition of culture (STEMAC) [12]. The evolution of scientific techniques opens new doors for cultural and archaeological evolution [13-15], the details of which are outlined here in Sections 2 and 3.

Today, humanities and archaeology, in particular, need to engage in discussing the implications of the expanding frontier of knowledge, ranging from archaeo-genetics to the diet and mobility of individuals, incorporating demography and sustainability in the long-term. We can now revisit museums and archaeological sites and select materials in order to reconstruct the whole life stories of individuals, in addition to their diet, mobility, and close family stories, as well as their larger genetic family stories from prehistory until the present. Sedimentological and geoarchaeological data can be used to reconstruct the ancient environment. Thus, a new door is now open to previously hidden knowledge, which will once again reduce the amount of qualified guessing, thereby refining and redefining theory and interpretation. Moreover, these new techniques bring archaeology much closer to public awareness. 
All these new methodologies allow the development of a new strategy for connecting our more complete knowledge to a sustainable level for present society, with economic, political, and social implications. The present paper focuses on archaeometry's role in cultural heritage sustainability and development. Hence, the triptych of archaeometry, added value, and sustainability is approached for the first time. At this point in time, one can take note of Oscar Wilde verse of the 19th century, "nowadays, people know the price of everything and the value of nothing" (from The Portrait of Dorian Gray).

Sustainable development is a balance between society, the environment, and the economy, which, in turn, interact and/or grow with specific groups of people, companies, and stakeholders, for whom archaeometry can play a significant yet neglected role (Figure 1). Thus, the objectives and working policy of the present paper address sustainable development through the lens of archaeometry.

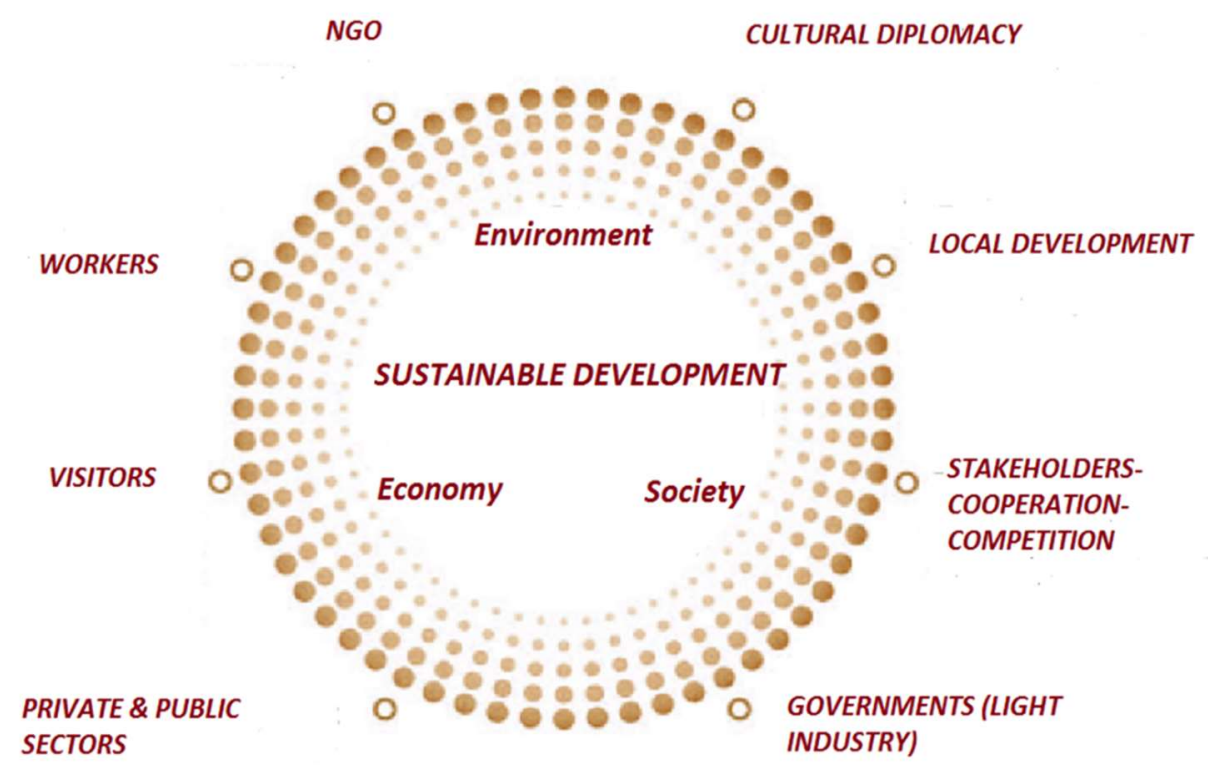

Figure 1. The holistic approach of sustainable development to the environment, the economy, and society, where archaeometry is encompassed and potentially may emerge from within the proper handling of each named agent.

The novel development of cultural tourism due to archaeometric contribution implies by-product growth in the field of cultural heritage such as public names, bilingualism, protection and care of local culture and traditions [15]. The realization of current methods presumes disseminating archaeometric knowledge by:

- Virtual Reality in museums, documentaries with 3D goggles, etc.

- Information Communication Technology (ICT), computer and mobile applications (educational games, interactive tools, etc.).

- Summer schools, volunteer programs, workshops, community-led programs, participatory archaeology.

Therefore, heritage sites, especially when properly documented with scientific methods, are important cultural attractions in the World, with adults visiting a site, participation of children due to family and school visits, inbound tourism, and especially international tourists, thus extending economic benefit beyond the discovered archaeological sites and cultural heritage monuments $[16,17]$. Having said that above, the present article is a first-time written concept, fully documented, and detailed in cases, to cover this wide interdisciplinary field. As such, and, due to the diversified nature of the journal, the reader (s), owe to be fully aware and the text must be digestive, to serve its purpose. 


\subsection{Sustainability of Cultural Heritage through New Technologies: A Critical Evaluation}

Under the trend of technological progress, the methods used for interpretation, documentation and promotion of cultural heritage have evolved significantly over the last decades [18]. Modern technology and the digital revolution have fundamentally altered the way in which cultural images and applications are produced, distributed and accessed. The evolving field of using information and communication technology (ICT) for the benefit of cultural heritage has produced in a short period of time a wide range of applications for scholarly research, public information and marketing as well as management of cultural sites. It has also provided new tools for cultural heritage preservation, as well as access, interaction, and knowledge-sharing. In terms of documentation and interpretation, in particular, the contribution of sciences such as physics, chemistry, biology, earth sciences, mathematics, statistics, and computing are regularly used to enlighten specific questions in regard to the archaeological data. This multidisciplinary field engulfs the discipline of Archaeometry, which is a combination of archaeology by ultimate aim $(\alpha \rho \chi \alpha o v)$ and natural science by approach ( $\mu \varepsilon \dot{\tau} \rho \rho v)$, thus introducing a new scope to the solution of questions [19]. Archaeometry techniques can document and communicate ancient artifacts, places and practices faster, in greater detail and with better perception amongst a broader public than ever before.

The archaeological work, which is by nature costly in time and money, is assisted by efficient methods which, in most cases, require a small amount of equipment and less labor expenses (For more information about non-intrusive archaeological survey techniques see Imogen Burrelli "What are non-intrusive archaeological survey techniques, and how they are used to archaeological advantages during excavations" in The Post Hole, Issue 36, March/April 2014, p. 8-13.). This is in accordance with the provisions of the European Convention on the Protection of the Archaeological Heritage (Valletta-Convention, Article 3), which states that non-destructive investigation methods should be applied wherever possible (the European Convention for the Protection of the Archaeological Heritage (revised) replaced and updated the original London Convention of 1969. It reflected the change in the nature of threats to the various types of archaeological heritage It established a pool of new basic legal standards for Europe, to be met by national policies for the protection of archaeological assets as sources of scientific and documentary evidence, in line with the principles of integrated conservation.).

Within UNESCO (The United Nations Educational, Scientific and Cultural Organization (UNESCO) is a specialized agency of the United Nations (UN) whose main objective is to contribute to peace and security by promoting international collaboration through educational, scientific, and cultural reforms in order to increase universal respect for law and human rights along with fundamental freedom proclaimed in the United Nations Charter http://www.unesco.org.) the specialized cultural agency of the United Nations, systematic efforts are made to ensure that all countries benefit from scientific and technological progress and innovation. This approach is in consistence with the United Nations 2030 Agenda for Sustainable Development, with its 17 Sustainable Development Goals. Within this framework the Organization promotes ICT that address specific challenges for the preservation of cultural properties, such as the impact of climate change and natural hazards. The 2005 Convention on the Protection and Promotion of the Diversity of Cultural Expressions recognizes that the protection, promotion and maintenance of cultural diversity are an essential requirement for sustainable development for the benefit of present and future generations and therefore promotes the use of new technologies and encourages partnerships to enhance information sharing and cultural understanding. In addition to the various investigations that have been carried out to date, the Parties to the 2005 Convention are gradually including digital applications in their quadrennial periodic reports, as they move forward in drafting operational guidelines exclusively focused on this topic.

The International Council on Monuments and Sites (ICOMOS) [20] on the other hand, which is the competent professional network that works for the conservation and protection of cultural heritage sites around the world, as well as the official technical consultant to UNESCO, is also promoting the use of modern technologies such as digital image processing, digital orthophoto production, terrestrial 
laser scanning, and 3D model processing in order to fully document the existing architectural heritage. Therefore, in case a monument is destroyed or damaged, and in order for the cultural managers to reconstruct, at least digitally, it is necessary for a full scanning project to have taken place beforehand. Although the subject of an actual reconstruction is still debatable among scholars the perspective of being able to retrieve, with the use of modern technology, data concerning a ruined or extant monument with the use of modern technology is undoubtedly worthwhile. The introduction of digital technology in the field of preservation and documentation of monuments has engaged extensive conversation on principles of reconstruction of cultural heritage and has contributed in somewhat shifting the overall negative position towards it. According to the Burra Charter (Australia), reconstruction can only be accomplished when a site is incomplete through damage or alteration, and enough evidence exists to reproduce the earlier state of the fabric of the monument. Here is where ICT come into the picture. The information system generated by digital photogrammetry and geographical information systems (GIS) leads to the efficient use of data, in a cost-efficient way, which is very valuable for saving cultural properties. The loss of many monuments due to armed conflicts raging across Syria, Iraq, and other countries in the Middle East has spurred the international scientific community and many cultural organizations to apply all available technologies, such as 3D scans, drones, lid methodology, and satellites. Even individuals were encouraged to post photographs of monuments and sites before destruction, thus providing valuable tools to prevent the possible permanent loss of data for cultural heritage.

The application of ICT definitely has an impact on several aspects of heritage preservation and enhancement management policies. In earlier years, both UNESCO and ICOMOS were generally opposed to reconstructions, following the provisions of the Venice Charter, with very few exceptions (for example the reconstruction of the historic center of Warsaw in 1980s and the Mostar Bridge). The theoretical framework for adopting new technologies and archaeometry in the field of culture protection and preservation has been formally introduced within ICOMOS with the approval of the Interpretation and Presentation of the Cultural Heritage Sites Charter, also known as Ename, which was the first international text ratified by ICOMOS to recognize the importance of using virtual reconstructions in the field of archaeological heritage. Among others, in Article 4.2 it recommends that "Visual reconstructions, whether by artists, architects, or computer modelers, should be based upon detailed and systematic analysis of environmental, archaeological, architectural, and historical data, including analysis of written, oral and iconographic sources, and photography. The information sources on which such visual renderings are based should be clearly documented and alternative reconstructions based on the same evidence, when available, should be provided for comparison". Through this text archaeometry became officially the prime collaborator of cultural sciences.

Furthermore, a special Committee has been established, within ICOMOS, the International Scientific Committee on Interpretation and Presentation of Cultural Sites, with the task to study the evolving technologies and techniques of data interpretation and presentation, to evaluate their potential to enrich contemporary scientific discourse and to focus on the experiential dimension of visits to cultural heritage sites, particularly by means of various media and methods of public communication.

In 2009, the London Charter on the Computer-based Visualization of Cultural Heritage was signed and approved and until today it constitutes the most important document of the international community in the field of cultural heritage and new technologies.

The Charter of Krakow (2000, Article 5) on the Principles for the Conservation and Restoration of Built Heritage, included for the first time, as Article 5, a specific recommendation for the use of new technologies in the field of archaeological heritage: "In the protection and public presentation of archaeological sites, the use of modern technologies, databanks, information systems and virtual presentation techniques should be promoted". This addition, unprecedented in other previous charters, marks an important turning point in the use of information technology as a tool in the regular work of conservation and presentation of archaeological heritage. Consequently, it should be considered as 
an important milestone in the history of virtual archaeology, leading through these new tools to the sustainability of cultural resources.

Several issues regarding the implementation of modern technologies to assist archaeological research have been thoroughly examined and evaluated by experts and cultural organizations, in an effort, to draw an effective framework with respect to the cultural heritage ethics. Under this perspective, for example, the European Archaeological Council (EAC), realizing the new possibilities that digital technologies are opening up for the promotion and presentation of archaeological research and investigation, EAC has organized in 2016, on the occasion of its annual meeting, a conference titled "Digital Futures: Archaeology in Europe" with the scope to explore developments in digital technologies and to consider how they may become embedded in general archaeological policy and practice over the next few years. The economic growth from new technologies implemented via the archaeometry applications in cultural heritage is at high stake if properly managed and becomes a new way to sustainable Development. Additionally, culture is "a drive and a catalyst of sustainable development" (UNESCO).

\section{How Archaeometry Works for Sustainability}

Archaeometry inheres two roles and needs reformations towards sustainability and development: the indirect (related to intangible culture) and the direct (tangible) [21]. That is a revisit of existing monuments and artifacts with new methods and techniques from physical sciences (Figure 2).
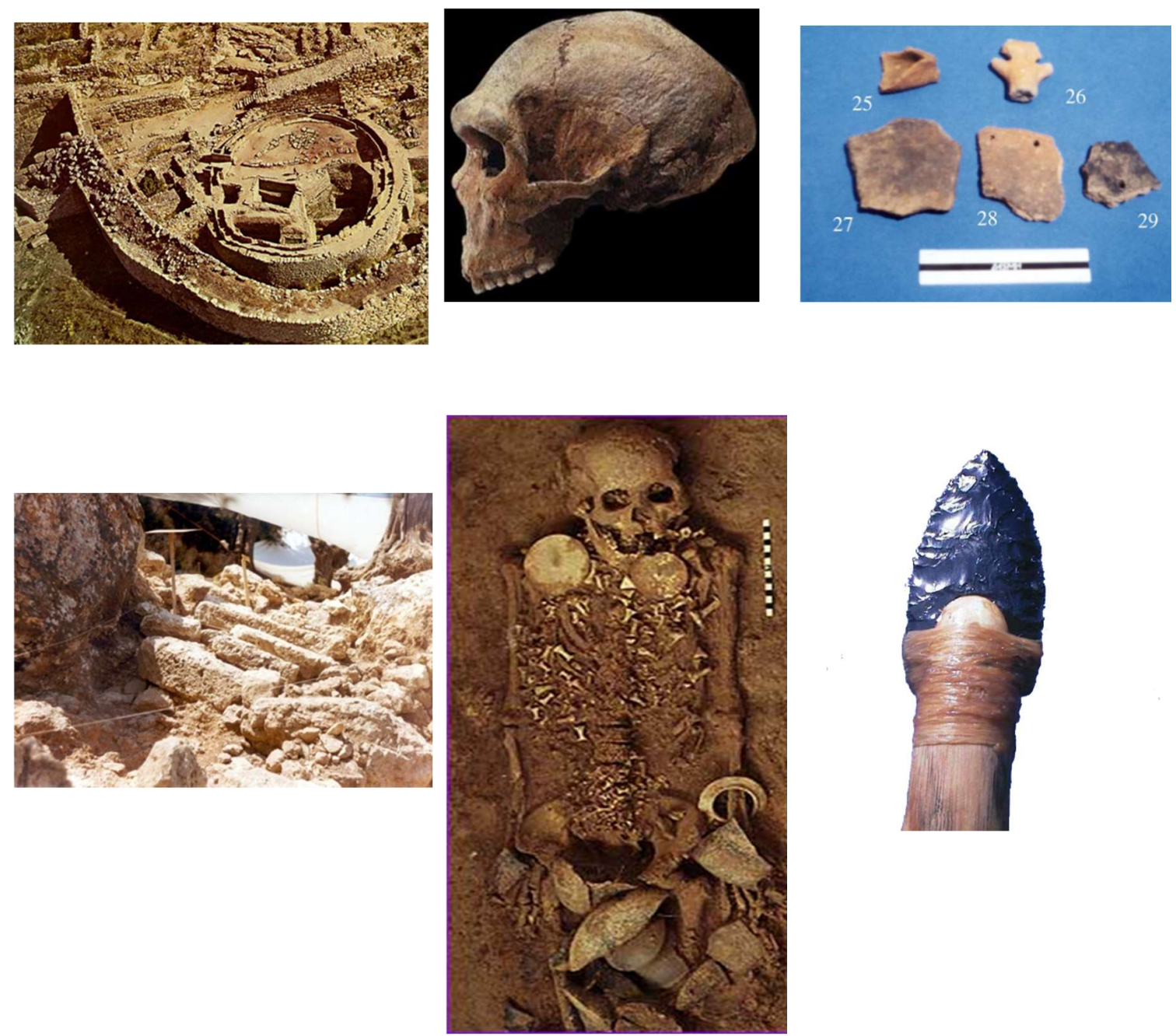

Figure 2. Some monuments and artifacts studied by archaeological sciences methods. 
This requires proper implementation of cultural politics accompanied by strategies, to fulfill the provisions of Article 5 of the London Charter: "Strategies should be planned and implemented to ensure the long-term sustainability of cultural heritage-related computer-based visualization outcomes and documentation, in order to avoid loss of this growing part of human intellectual, social, economic and cultural heritage".

Several questionnaires to the public regarding attractive presentation of museum exhibits and cultural monuments, point to the urgent need for new technologies to show up archaeological and archaeometrical data. For example, comparing the user response before and after virtual reality (VR) demo, there is a clear sign of increased level of interest and cultural heritage awareness with increase in likelihood that the user would tell others about the sites after viewing the VR demo [22,23].

The means of reforming are:

(A) Applied informatics, geoinformatics (computer-human interaction, IT, computer sciences, geographical information systems (GIS) [24].

(B) Documentation of museum objects [25,26].

(C) Management of archaeological sites and museum tasks concerning cultural heritage (improve in quality, accessibility, reclaiming of digital content) [27-29].

(D) Multimedia technologies, digital reconstructions, simulation of artifacts and monuments, and 3D VR. Combining never-before-published aerial and remote sensing photography and high-definition, $3 \mathrm{D}$ computer reconstructions with clear, informative descriptions of the various sites, innovative descriptions of the various terrestrial or underwater sites. These ways use the latest scientific and archaeological tools to visualize the wonder of the past [30-35].

(E) Discovering new buried monuments, making cultural parks, and developing cultural tourism $[36,37]$.

(F) Exhibition, dissemination, pedagogy fostering of archaeometrical results, made popular to the society via digital means $[38,39]$.

The development targets derived thereof are on:

- Cultural tourism;

- Social coherence;

- Employment; and

- Development of innovative applications (digital).

The "tourism" has a multidimensional face and "cultural tourism" is a vital component, as each country has a cultural rooting which fits as cornerstone in the global cultural unity (Figure 3). Using techniques borrowed from the entertainment industry, more and more archaeologists are boosting their imaginations and insights with virtual worlds.

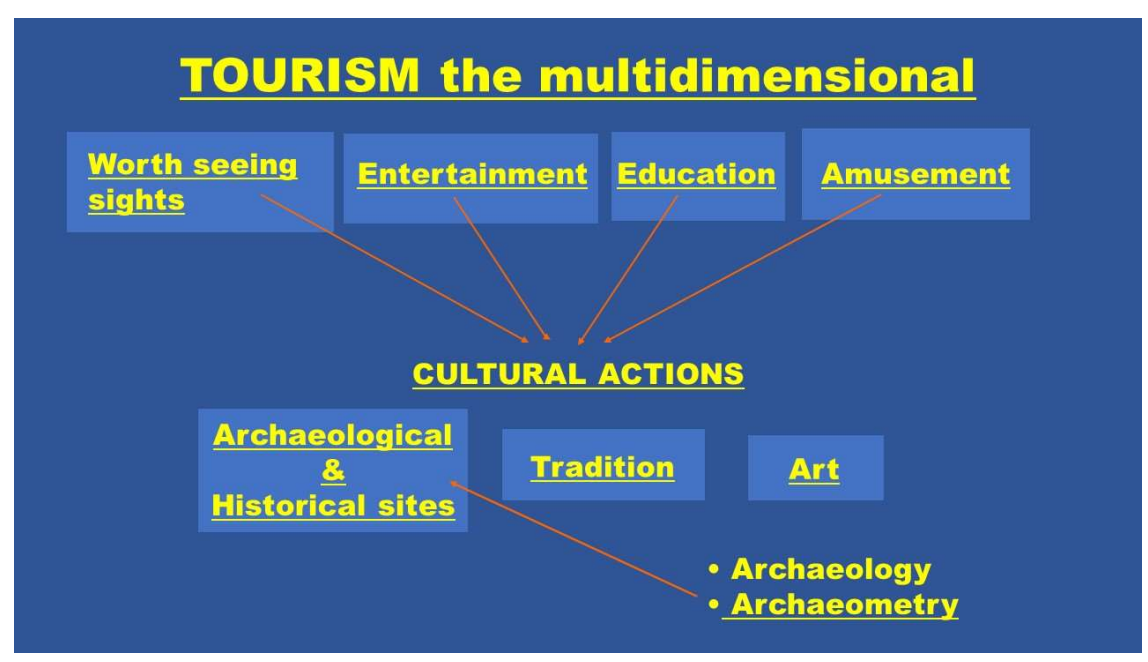

Figure 3. The multi-faceted tourism. 
With combined new technologies, in museums, archaeological sites and parks, and reanimating their seemingly "dead" nature, it adds getting closer to the interest of layman, professional and trade market (visitors, scientists, students, stakeholders).

Some selective major archaeometrical case studies with respective economic impact are described below.

\section{Some Archaeometric Case Studies with Economic Impact}

\subsection{Characterization and Provenance}

The analysis of ancient archaeological finds is of interest, and it provides clues on the technology of production, the used ingredients, the raw materials, the local production or traded goods. Additionally, the possibility of the reconstruction roots develops scenarios of reconstruction of implements used by ancient societies. Amongst thousands of relevant studies one example is chosen here. For example, the study of prehistoric amphorae provenance based upon their chemical analysis via neutron activation analysis provided clues regarding their mobility in the prehistoric Aegean (Figure 4). Modern techniques allow non-destructive analysis of artifacts, an advantage in the sampling procedure and issues regarding preservation and legalities of evasiveness of precious works of art.

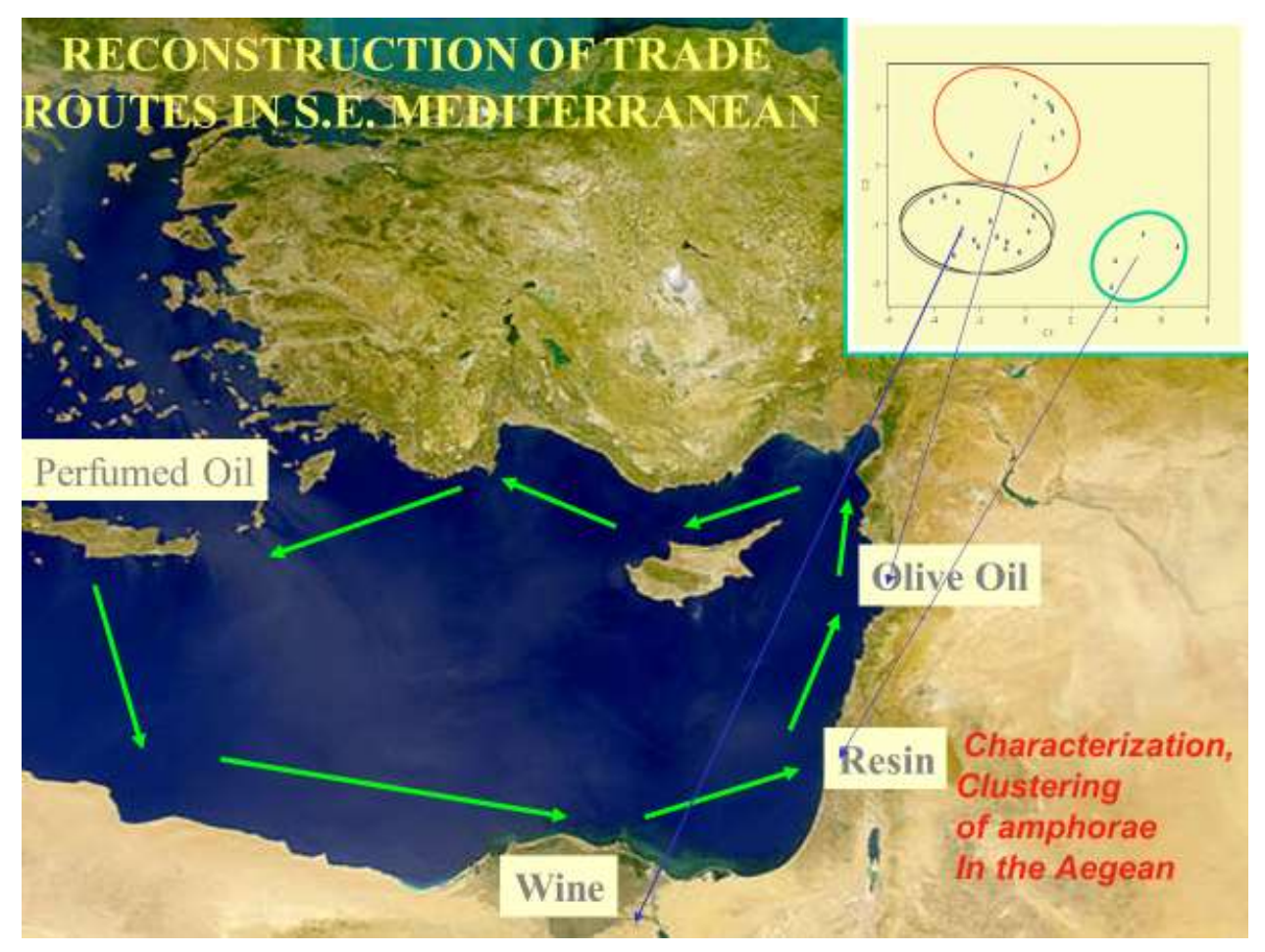

Figure 4. An example of trade in the prehistoric Southeast Mediterranean. Late Bronze Age prehistoric amphorae chemical analysis via neutron activation provides clues regarding their mobility in the prehistoric Aegean. Statistical clustering with principal component analysis (PCA) identified the origin of traded contents (oil, resin, wine, perfumed oils). In the inset, a plot of PCA components C1 vs. C2 and the resulting groups from respective regions (e.g., 39).

The portability of instruments has solved scientific issues allowing analysis in situ or of museum exhibits and not transferring the artifacts to the laboratory. Moreover, non-destructive methods of physico-chemical analysis contribute in the conservation work of monuments and artifacts and in their preservation and restoration of organic and inorganic materials [18,40-44]. 
In addition to the conservation procedures applied for exposition in museums more information on the investigation of contents in these artifacts helps our knowledge of the past and increases the interest and attention to visitors and strengthens cultural tourism.

\subsection{Locating Buried Monuments}

Geophysical prospecting aims to detect and map concealed antiquities and has been employed in the archaeological practice since the end of the Second World War.

Geophysical prospection has been also employed in non-conventional manners to tackle specific archaeological problems. Such problems might be, for example, the cases of locating tombs under tumuli embankments, assessing the moisture content in walls, the depth of fractures in sculptures, exploring the space behind walls, mapping the waterways along which the water drains out or in monuments, investigating in urban environment, etc. Relatively recently, the potential of this kind of operations has been the subject of numerous papers. However, many of these operations require a great amount of expertise and innovation [37,45-48].

Further, surface magnetic susceptibility may have been mapped, or electromagnetic data may have been collected. Additionally, aerial and satellite images might be available for the particular site, plus lidar images and accurate digital elevation models (DTM) [49,50].

Each one of the aforementioned methods is sensitive to different physical properties. Presumably, the combination of the information that each method provides could yield much better constrains in identifying, mapping and finally documenting the archaeological targets.

Geophysical prospecting at archaeological sites contributes to the sustainable development of specific provinces and areas. In particular, wide areas can be easily explored by (archaeo-) geophysical prospection, while under favourable conditions this approach may produce ground or underwater views of the buried ancient vestiges. Hence the following digs focus on pointed targets; as a result of saving capital, time, and effort. Accordingly, areas can be evaluated and included in local or regional development planning.

An archaeological dig may be shown in a holistic manner making use of cyber-archaeology, exhibiting the unearthed parts and displaying the parts that still reside underground in plates, leaflets, movies, etc.

The non-evasive archaeo-geophysical surveys are most significant in unearthing buried antiquities and offer a cultural attraction and development. It contributes a great deal to sustainability. Hidden antiquities are revealed. Many projects have been implemented where geophysical investigations have helped to exhibit new archaeological sites, either underground or under the sea, and restrict illicit excavations and trafficking of antiquities, and protecting at-risk antiquities from either public works or environmental risks.

There exist a number of examples from all over the world, especially from countries with a rich cultural heritage. The numerous archaeo-geophysical prospection (electrical, magnetic, georadar, remote sensing satellite imaging, and seismic sounding) first detect the buried target, which was followed by archaeological excavation, a study of the finds, and conservation and restoration tasks, to finally manage the opening the archaeological site and associated museum to the public, acquiring a sustainable character, such as in Italy with a significant project in South Etruria by the British School in Rome and Italian authorities (http:/ / www.bsr.ac.uk/research/archaeology/completed-projects / tiber-valley-project/south-etruria-survey) [51], and in Egypt, China, Turkey and other parts of the world [52].

Reports of a number of examples exist from the Aegean region (Greece) that geophysical investigations have driven the archaeological investigations to a surgical kind of excavation and, at the same time, contributed to the promotion of the sites and the general prominence of them. Just to mention some of them, next to the Neolithic settlement of Dimini, integrated geophysical approaches (magnetic, soil resistance, electromagnetic techniques) were responsible for mapping the residues of two large monumental megaron-type compartments that were identified with the 
foundations of the Mycenaean palace that was subsequently excavated fully and was identified with the settlement of Iolkos in Thessaly, Greece, the home of Homeric King and hero Achilles. Today, it is accessible to visitors and it is one of the main archaeological attractions of the region [53]. Similar kinds of investigations with a subsequent steady increase of visitors have been carried out in the area of the Sanctuary of Poseidon at Kalaureia on Poros island. The subsequent excavations by the Swedish Institute at Athens revealed a number of structural remains that were associated with the daily activities of the site $[54,55]$. On Therasia island, despite its remote location and the hardness of the volcanic environments, geophysical measurements at the monastery of Koimisi and Orycheia produced substantial evidence related to the habitation of the island during the Early and Middle Cycladic periods (and most probably abandoned before the large volcanic eruption), as it was confirmed from the excavations that followed [56]. Even more examples can be presented for such cases where the geophysical survey has been able to contribute not only to the promotion of the sites, but also to their sustainability and their openness to the wider public since they have been excavated and offered to the visitors (the ancient Greek city of Sikyon [57]; the site of Bedenaki-Walls of Venetian Herakleio [58]; and the Minoan site of Sissi in Eastern Crete [59].

The cemetery of the Roman Era of Europos, Northern Greece, comprises another example. It is situated at the foothill of a topographic table. In fact, the resistance prospecting at this particular area yielded the distribution of resistances displayed in Figure 5a [37]. Its interpretation is straightforward since pronounced high resistivity anomalies are surrounded by a rather uniform low resistivity environment. The "twin probe" electrode arrangement was used having the roving electrodes $1 \mathrm{~m}$ apart, one form the other, and 1 and $2 \mathrm{~m}$, in line and cross line spacing, respectively. Therefore, it was a low-resolution survey aiming only to detect and map the position and the areal extent of large monumental tombs. Presumably, each one of the well-defined in space high resistance anomalies has been caused by such a concealed structure. On the other hand, the relatively sizeable blurred anomaly at the west side of the image was attributed to a hidden gravel deposition. In fact, after the excavations, the aforementioned interpretation proved true in all its predictions.

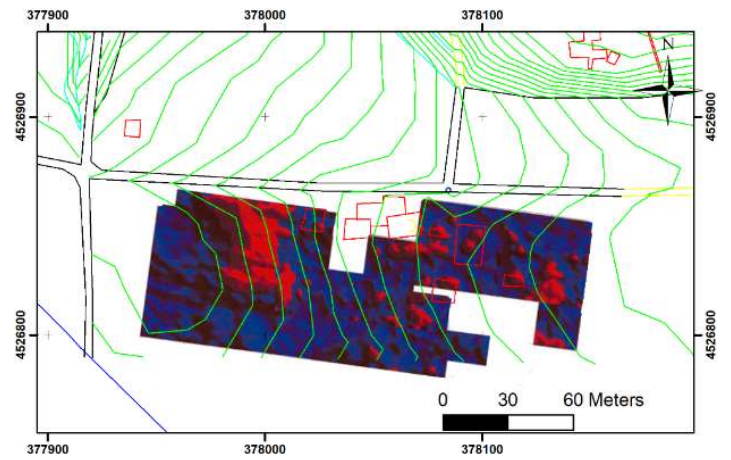

(a)

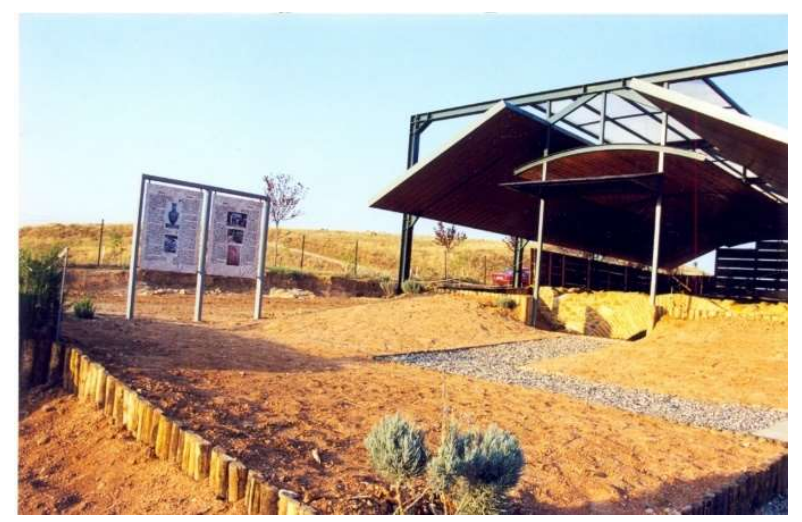

(b)

Figure 5. (a) Resistivity prospecting of the Roman era Europos site exhibited the distribution of iso-resistances and pseudo-colors displayed, where high resistivity anomalies are surrounded by a rather uniform low resistivity environment [37]; (b) The site as an archaeological park. The plate shown introduces the visitors to the whole adventure to unearth and promote the monuments, from the geophysical image to the final stages of designing the shelters and organize the accessibility and promotion of the site where revealed tombs and architectural remains are now a tourist attraction to visitors (@ G. Tsokas pers. comm., 2019).

The geophysical investigations guided the excavations (headed by archaeologist Dr. Thomais Savvopoulou) to the revelation of many monumental tombs, unfortunately all of them almost 
completely looted. However, the area was recreated to an excellent archaeological park (Figure 5b) contributing to the development of the particular province of the Greek State.

Why, after all, is geophysical prospection useful? It reveals hidden antiquities from a tomb to a city and others, by discovering buried ancient relics, it results to the creation of archaeological parks, museum exposition, other cultural activities, and in the updating of historical information with digital technology, all of which contribute to the local sustainable market. The ability to provide reliable images of the subterranean antiquities renders geophysical prospecting as an invaluable tool for the archaeological research, cultural heritage planning. Consequently, by assisting the archaeological research and promotion of monuments, which in addition, are studied by other archaeometrical methods, all is a decisive factor in the cultural tourism and economic growth.

\subsection{Cyber-Archaeology and Bio-Archaeological Issues}

The novel technologies and instrumentation development have achieved a goal: use of "Big Data", the new quantitative modelling and the results from aDNA, strontium and other isotopes and related scientific methods, have produced a new concept in contemporary archaeology $[18,60,61]$.

The new technologies indeed alter our lives and the way in which we perceive it beyond the imaginable. This further ulterior over is the point in space-time in which coalition of science, technology, and art openly combined for the 3rd Cultural Revolution, and for environmentally sustainable abundance. However, this time, the "beyond" not only explores the dynamic 3D screen, it moves on from the bits to the atoms and incorporates 3D-printing and digital cloud-distribution which combined to relevant scanning or photographic technologies create a virtual environment as a real world. We are entering the central source for current and emerging trends in cultural heritage informatics with new disciplines, sub-disciplines and terminology to emerge. Virtual, cyber-archaeology, and cultural heritage to cyber-archaeometry are matters that have been recently tackled [18,62].

The virtual archaeology case studies, over the world, as a result of advanced technology emerging from computer sciences, however, stress the naturalistic methodology, and challenges digital reconstructions and serious games. There may also be provocation and harassment and the emergence of fundamental hermeneutical questions which serve as the basis of a synoptic and synthetic philosophy that combines art and science corresponding to classical techne, logos, and ethos.

The need for objective methodologies point out the need of hyper-taxonomies for interpreting the past, leading computing archaeology to an objective "scientific" interpretation [63-65].

The VR, 3D modelling and metadata, serious gaming, digital 3D reconstructions of bioarchaeological and cyber-archaeology data, all build a virtual collection and dataset and enrich the cultural heritage repertoire via virtual museums and make such archaeological heritage accessible to the public $[64,66]$. Hence, "the websites of museums seem far more reluctant to display the dead online ... It might also relate to the fear of de-contextualising human remains" [67].

Increasingly, institutions are also understanding that much of their public engagement will now take place digitally, with platforms acting as a "medium through which information is published or exchanged" [68] though bio-archaeological data are contrasted with a critical review of current ethical and technical guidelines, indicating potentially ethically compromising practices, particularly the lack of contextualising metadata for some models [69].

\subsection{The Antikythera Mechanism}

The Antikythera mechanism is the world's first analogical computer, used by ancient Greeks to chart the movement of the sun, moon and planets, predict lunar and solar eclipses and even signal the next Olympic Games and bearing inscriptions [70] (Figure 6). 


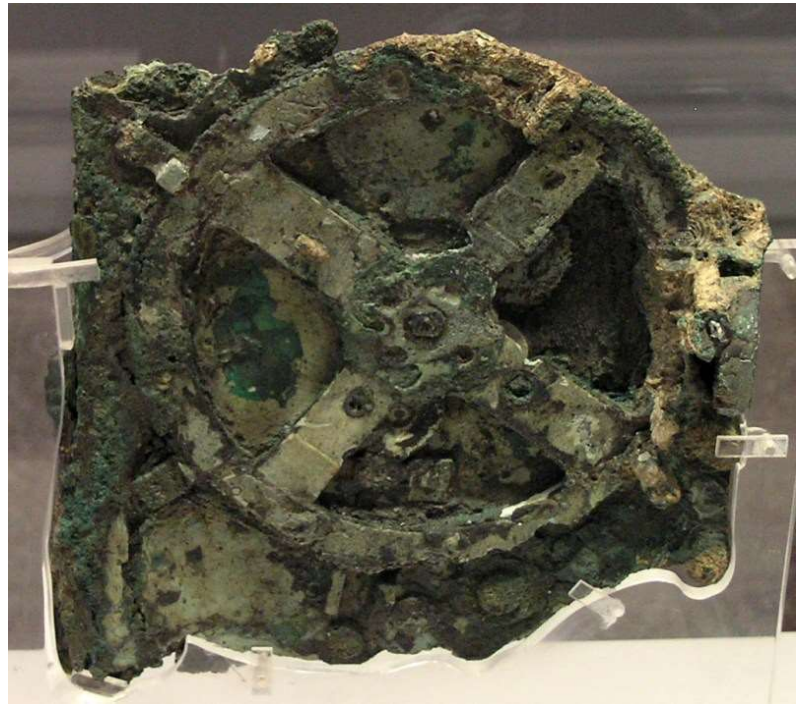

(a)

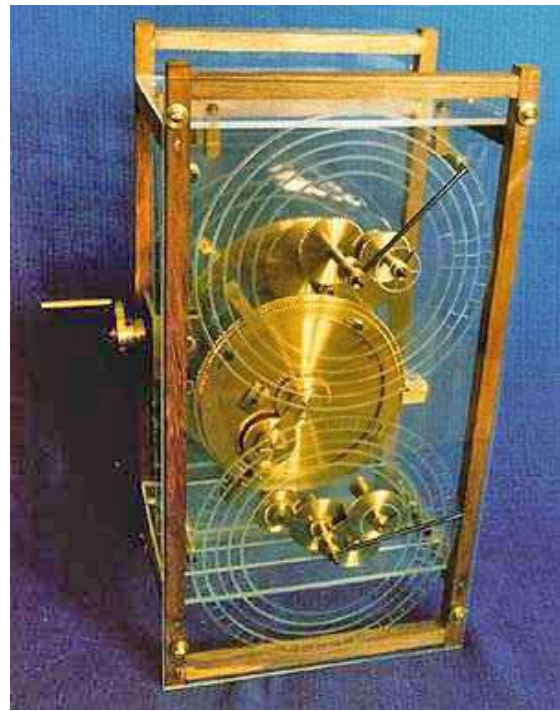

(b)

Figure 6. Antikythera mechanism, one of the pieces displayed in Athens Archaeological Museum, and a reconstruction of back dials ((a): National Archaeological Museum, Athens, photographer: Kostas Xenikakis, copyright Hellenic Ministry of Culture and Sports / Archaeological Receipts Fund; (b): Model constructed by John Gleave, according to Derek de Solla Price [71,72]).

The 2000-year-old astronomical calculator is a small size metal device. The detailed X-ray tomography imaging of the interior revealed at least 30 meshing bronze gears, was used for the determination of time, and included a user's guide of operation; new data proved its use as an astronomical device, and a 3D reconstruction has been made. Despite its poor condition, crammed insides, obscured by corrosion, it showed traces of technology that appear utterly modern: gears with neat triangular teeth (just like the inside of a clock) and a ring divided into degrees. It is a unique discovery from antiquity, and beyond doubt the only sophisticated, unparalleled object appears again for more than a thousand years. In particular, it calculated the prediction of eclipses, recorded the zodiac and the Egyptian and Greek Calendars, the solar-lunar calendar, the 19-year Cycle of Meton, the Saros cycle or exeligmos, Greek inscriptions, markings of astronomical symbols on discs, and the determination of major cultural events (Olympia, Pythia etc.), and cycles of 19, 76, 18+, and 54+ years [73-76].

The management of the revealed data and use of modern archaeometrical techniques had a respectful impact of increased visits in the National Archaeological Museum, Athens.

Moreover, a review of the published news in the media have shown a social interest and awareness, contributed to the cultural tourism, added to the international visibility-cultural diplomacy, become a paradigm of true interdisciplinarity, with the 3D reconstruction to provide an attraction to visitors, especially students (Table 1).

Table 1. Visits in the national archaeological Museum of Athens, 6 April 2012-28 April 2013. For 2012-2014 the total visitors were 800,000 .

\begin{tabular}{ccc}
\hline \multirow{2}{*}{2011 (before the Exposition) } & Visitors & $\mathbf{3 2 , 7 2 3}$ \\
\cline { 2 - 3 } & Students & $\mathbf{3 8 , 4 7 4}$ \\
\hline \multirow{2}{*}{2012 (Year of exposition) } & Visitors: & 153,581 \\
\cline { 2 - 3 } & Students & 47,958 \\
\hline \multirow{2}{*}{2013 first 3 months (January to March) } & Visitors & 56,896 \\
\cline { 2 - 3 } & Students & 29,141 \\
\hline
\end{tabular}




\subsection{The Ice Man "Otzi" in the Alps}

The ice man 'Otzi' (this name refers to the discovery site in the Ötztal Valley in the Alps) is a glacier mummy from the Early Bronze age (3300-3100 B.C.) Central European Alps and has been preserved to the present day. He was discovered accidentally by hikers in 1991, together with his clothing and equipment, on the Schnalstal/Val Senales Valley glacier and has been the subject of intensive research. Ötzi and his artefacts have been exhibited at the South Tyrol Museum of Archaeology in Bolzano, Italy since 1998. Following a thorough archaeometrical research the mummy is stored in a specially devised cold cell-a glass vitrine with controlled temperature $\left(-6{ }^{\circ} \mathrm{C}\right)$ and humidity $(98 \%)$ at glacier-like conditions. Ötzi's numerous pieces of equipment and clothing have been painstakingly restored. The magnificent work of conservation, exposition, and reconstruction of this mummy has been initiated by the holistic archaeometric contribution. Techniques applied and materials measured include: (a) radiocarbon $\left({ }^{14} \mathrm{C}\right)$ dating of clothing, wooden bow, and bone $[77,78]$; (b) X-ray flourescence (XRF) of hair discovering traces of copper and arsenic, implying his involvement in early pyrotechnology of smelting copper [79]; (c) X -ray radiography of his whole body discovering the fatal flint arrow in his left back shoulder, and other injuries [80,81]; (d) bio-archaeology used to decoding the Iceman's genetic make-up through aDNA, as well as carbon, oxygen, nitrogen, and strontium isotopic analysis in his teeth and bones proved his southern of Alps (Italy) origin, while he had eaten three meals during the last day or so, including a final meal about two hours before he was killed. Methods of thermal ionization (TIMS), inductively-coupled plasma (ICP-MS) and gas mass spectrometry included isotope ratios of ${ }^{18} \mathrm{O} /{ }^{16} \mathrm{O}\left(\delta^{18} \mathrm{O}\right),{ }^{87} \mathrm{Sr} /{ }^{86} \mathrm{Sr}$, and ${ }^{206} \mathrm{~Pb} /{ }^{204} \mathrm{~Pb}$, in order to reveal the Iceman's origin and migration behaviour. Analysed samples include tooth enamel, bones, and contents of his intestine, which all represent different ontogenetic (developmental) stages [80,82-85]; (e) palynology for pollen contained within the foods consumed by Ötzi, along with other palaeopathology evidence, colleagues were able to reconstruct his hectic itinerary in the hours before he died and defined the late spring/early summer death incident as well as the archaeobotanical environment [86]' and (f) virtual reconstruction of the Ice Man Otzi and his equipment, showing how he was equipped for the harsh temperatures of the high mountains and his clothing, in a reconstruction [87].

The impact to cultural tourism through increased number of visitors in south Tyrolo, and especially the Otzi museum, was perceptible (Figure 7). The museum attracts a variety of groups: school groups, the local population, visitors from further afield and from abroad. Ötzi and the South Tyrol Museum of Archaeology represent the main cultural destination in adverts promoting tourism in South Tyrol abroad, attracting a great many visitors and are, therefore, a not insignificant economic factor. A large number of them have not come to the regional capital for a holiday, but are day-trippers to Bozen-Bolzano, enjoying a perfect mix of sightseeing, shopping and local specialties, and of course to visit Ötzi in the South Tyrol Museum of Archaeology. This mixture of activities has an economic ripple effect: South Tyrol scores as a holiday destination with its attractive museums, and the many people who come to Bozen-Bolzano have a positive influence on the creation of added value and on the tourist facilities and services on offer. Since its opening on 28 March 1998, the museum has been visited by 5 million people; in 2017 by 286,972 visitors [88]. 


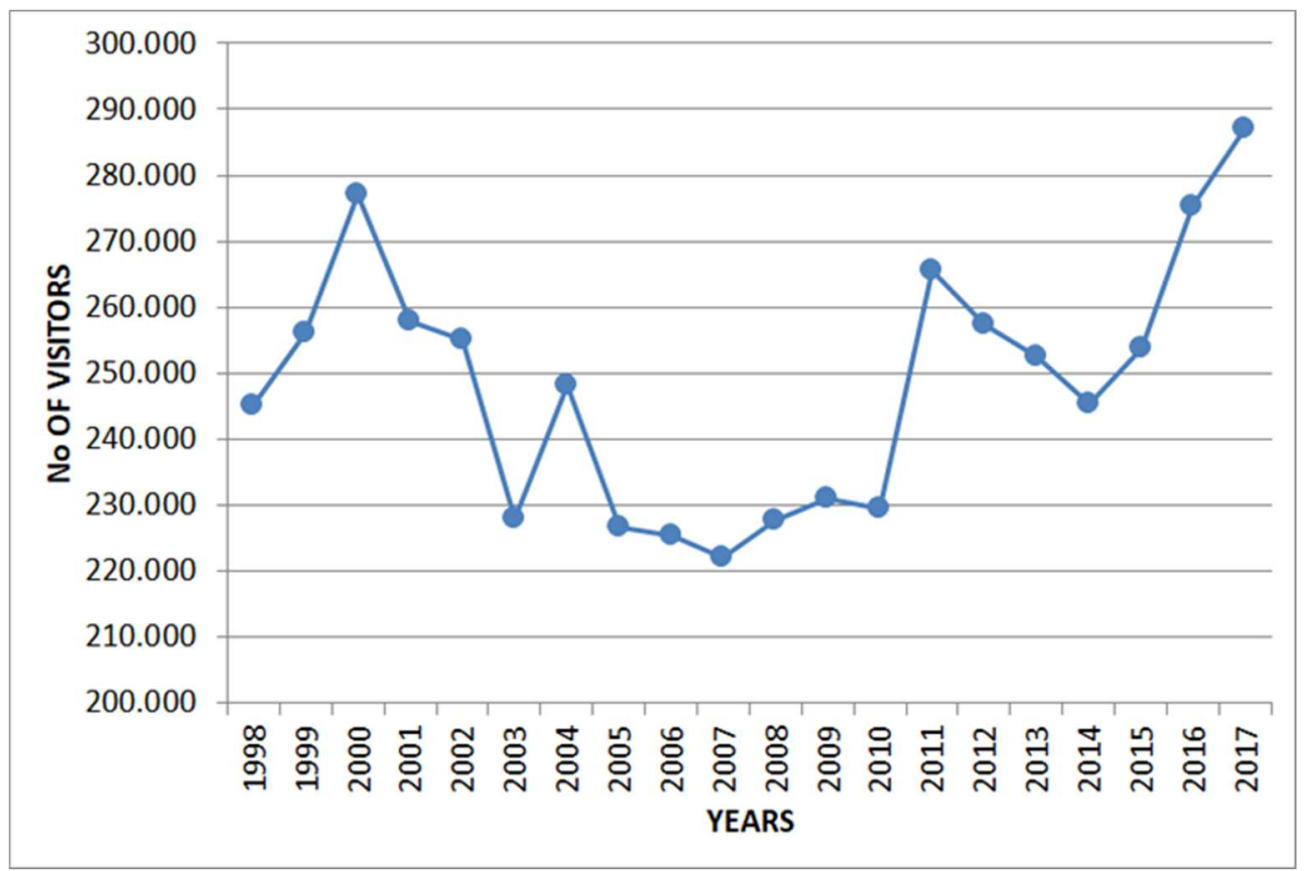

Figure 7. Trend of visitors per year from 1998 (opening) to 2017 ([89]. The peaks at 2000 and 2011 denote significant news information in the previous or running year from published data derived from more archaeometrical analysis of Otzi and properly disseminated through multimedia. Since 1998 (opening) it attracts 250,000 visitors/year. From a financial point of view, the museum has revenues from tickets sales, merchandising, sponsors, and publishing (see also [90]).

\subsection{Archaeoastronomy in Stonehenge, England}

Cultural heritage related to the sky (archeoastronomy) is a vital component of cultural heritage, in general, and recent UNESCO's Astronomy and World Heritage Initiative, supported by the International Working Group on Astronomy and World Heritage and by the International Astronomical Union through its Commission C4 on World Heritage and Astronomy emphasizes its added value [91].

The prehistoric monument of Stonehenge has long been studied for its possible connections with ancient astronomy (Figure 8). The site is aligned in the direction of the sunrise of the summer solstice and the sunset of the winter solstice. Archaeoastronomers have made a range of further claims about the site's connection to astronomy, its meaning, and its use.

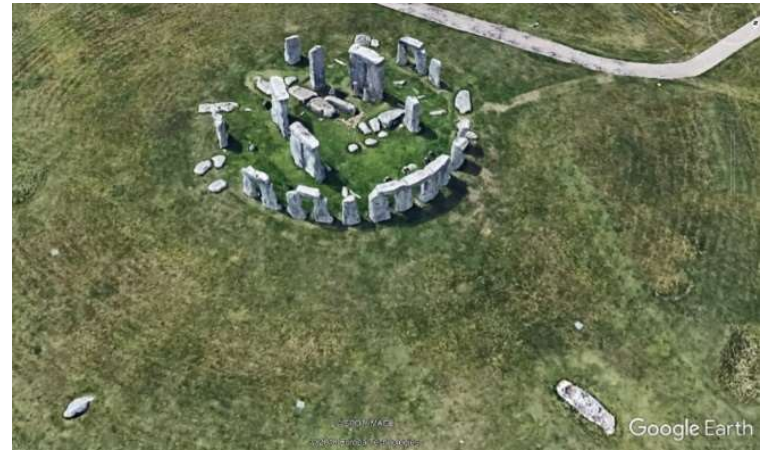

(a)

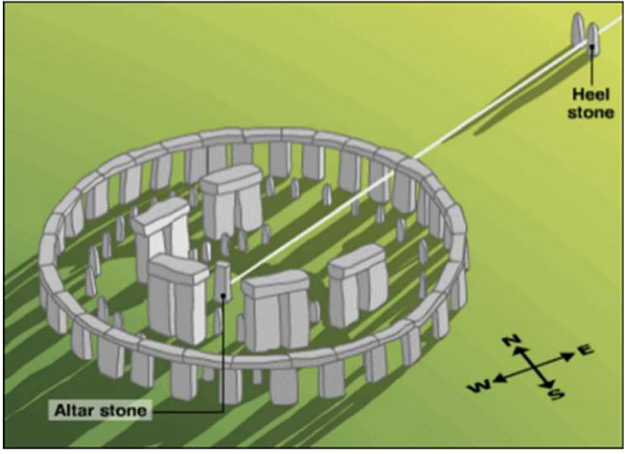

(b)

Figure 8. (a) Stonehenge from Google Earth and (b) 3D rendering and reconstruction showing the summer solstice sunrising light beam [92]. 
Early attention regarding the astronomical significance of the monument include: Stukeley [93], famous astronomer Edmund Halley, Sir Norman Lockyer (founding Editor of the journal Nature), and others [94-98].

These 3D studies and reconstructions and laser scans, video tours [99] together with ${ }^{14} \mathrm{C}$ dating both have boosted and enhanced its archaeological and astronomical significance [100-102].

Stonehenge's use is still not known but it is accepted as part of a ritual landscape. Whatever religious, mystical, or spiritual elements were central to Stonehenge, its design includes a celestial observatory function, which might have allowed prediction of eclipse, solstice, equinox, and other celestial events important to a contemporary religion.

Stonehenge has become an increasingly popular destination during the summer solstice, with 20,000 people visiting in 2005, scholars have developed growing evidence that indicates prehistoric people visited the site only during the winter solstice (Figure 9). An increased number of visitors is observed, especially after the opening in December 2013 of the new visitor centre which houses permanent and temporary exhibitions, enhanced with more archaeometrical results as they become available annually for the monument.

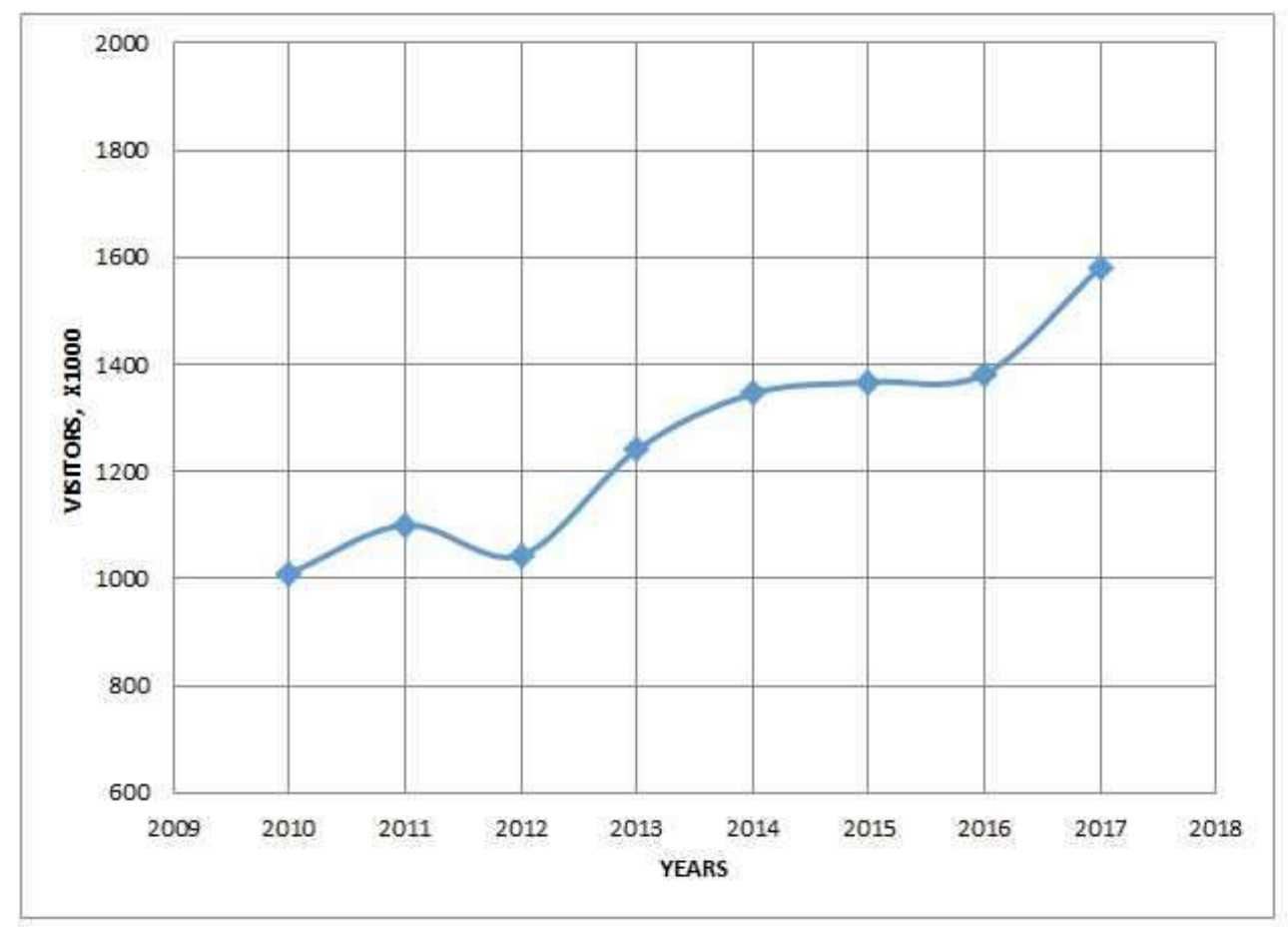

Figure 9. Visitors in the Stonehenge during 2010-2017 [103].

The only megalithic monuments in the British Isles to contain a clear, compelling solar alignment are Newgrange and Maeshowe, which both famously face the winter solstice sunrise.

The most recent evidence supporting the theory of winter visits includes bones and teeth from pigs which were slaughtered at nearby Durrington Walls. Their age at death indicating that they were slaughtered either in December or January every year

Archaeological research and archaeometric measurements consider it was constructed from 3000 BC to 2000 BC but re-used at later times to at least the Late Bronze Age.

One of the most famous landmarks in the United Kingdom, Stonehenge is a legally protected Scheduled Ancient Monument since 1882 when legislation to protect historic monuments was first successfully introduced in Britain. The site and its surroundings were added to UNESCO's list of World Heritage Sites in 1986.

Other monuments built in accordance with astronomical alignments are potential tourist attractions if properly managed with new technologies. 
Several potential or ongoing archaeometrical projects properly managed could with certainty become an added value and lead to an enhanced cultural tourism. Prior to completion of an archaeological-archaeometrical project, that is, the archaeological site and exhibition museum open to the public, but during the implementation of the program, at the level of summer schools and field work by groups of students and research institutes, the necessary expenses on a daily basis for the research investigators contributes as the economic stimulation to the local society. Hence, three factors are reinforced; social cohesion, economic benefit, and scientific development.

\subsection{A Recent Combined Project in Kaifeng, Henan (China)}

Geophysical prospection, photogrammetric techniques, (LIDAR, GIS, GPS, etc.) were applied to locate and reveal the ancient capital of China at Kaifeng. It was the geophysical detection of sub-terrain relics that drove the archaeological service to start a large excavation enterprise. Six ancient cities buried deep underground and spanning several dynasties over 2000 years have been unearthed in Kaifeng, in the east of China's Henan province. Archaeologists and archaeometrists worked collaboratively at the Xinzheng Gate site, a gate on the wall of the ruins of Bianliang (Kaifeng's name during the Northern Song Dynasty, 960 to 1127 AD) [104,105] (Figure 10).

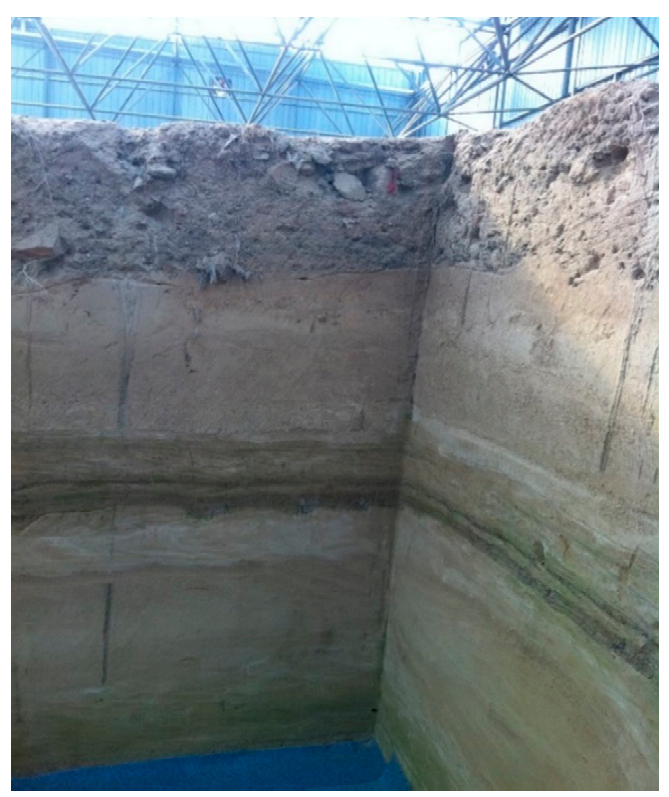

(a)

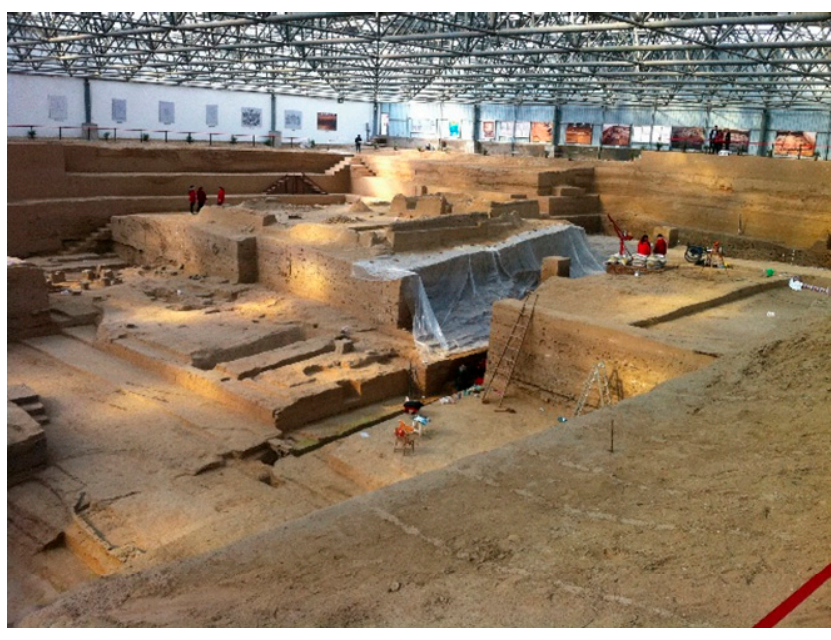

(b)

Figure 10. (a) Stratigraphy of the Kaifeng six city-upon-city, Xinzheng Gate site, (b) view of the ongoing excavation. Objects found are in the adjacent museum (photo $\odot$ by IL).

The 2000-square-meter site boasts cultural relics from the Warring States Period (475-221 BC) to the Qing Dynasty (1644-1911 AD), with each city piled one on top of another.

It includes city gates and walls from the Song Dynasty (960-1279 AD), roads from the Song to the Qing Dynasties, civilian homes and courtyards from the Qing Dynasty, plus courtyard walls from Yuan Dynasty (1271-1368 AD). An increased number of visits to the site and associated museum in Kaifeng has been noted as a result of government's efforts to capitalize on tourism has kicking into high gear.

\subsection{Conservation of Monuments, Castles}

The application of archaeometric techniques and conservation works to monuments and castles has proven the added value to the economy of a nation. Undertaken projects of such scale mainly require decision-makers' attention in the authorities of government [106]. 
Projects of this kind follow a series of protocols and necessary steps regarding documentation, evaluation, archaeometry, conservation, restoration, revitalization, and management [107] as outlined below (in bold those steps related to present paper's aims):

STEP 1: Natural environment (location, climate, geomorphology, geopolitics, GIS, flora and fauna)

STEP 2: Socioeconomic status (ownership, legal frame of the state and local community, economical activities of the region, resources, main occupation educational level)

STEP 3: Architectural, structural engineering, and technological data (designs of topography and architecture of the structures included. Survey of pathology and construction techniques. Documentation of old materials. Old regional techniques of construction).

STEP 4: Historical data (ethnology, recursion of the history, historic events, references, everyday life inside and outside the castles)

STEP 5: Evaluation of the selected data (definition of the basic axis or eminent characteristics which should be alleged and of the priorities of activities)

STEP 6: Archaeometry-conservation work (spectroscopic analysis, dating, mechanical properties, 3D documentation. Interventions for solidification conservation, cleaning, consolidation, pointing reconstruction, reinforcement of foundation sheltering, conservation of work of arts included in the ensemble)

STEP 7: Excavation for further archaeological documentation. Geophysical prospection (find data for "dark" historical periods)

STEP 8: Plans for the functional rearrangement of the site (access, protection of natural and architectural expression, lightening, readability of the history, outbuildings).

STEP 9: Plans for connection with other monuments of architecture (pedestrian, archaeological walk, place of sightseeing and relaxation)

STEP 10: Establishment and operation of monitoring system (Long-time behaviour of repaired parts, record of visitors. Regulations)

STEP 11: Digital reconstruction, digital scenarios, Virtual museum.

STEP 12: Use for educational purposes (Plans for regular and occasional activities in cooperation with local and state authorities)

STEP 13: Enhancement of cultural activities (festival, infrastructure for theatre performance, meetings, events).

STEP 14: Plans for development of local economy (ecotourism, local bus, guides for visitors, activation of the municipality and periphery in participation of joint development projects)

The development and gives a statistical result that helps unemployment and economy in general. Conservation and restoration projects in which the wide archaeometrical techniques and methods were applied has provided economic benefits to some countries.

In 2004 Italy's income of 14 billion Euros came from cultural tourism from conservation and restoration works (towns with history, monuments/works of art, restoration/conservation/preservation).

In $200215 \%$ of France's annual income, equal to about 15 billion Euros, came from cultural tourism of castles and monasteries, yet about 855 million Euros per year was used for archaeometry-conservation-restoration of cultural heritage.

Another characteristic and recent example is the "Integrated Diagnostic Research Project and Strategic Planning for Materials, Interventions Conservation and Rehabilitation of the Holy Aedicule of the Church of the Holy Sepulchre in Jerusalem". New technologies, including LIDAR, sonar, laser scanning, thermal imaging, georadar (GPR), and luminescence dating and characterization, were used to preserve this important site, as well as, the geometric documentation with materials analysis, the identification of building phases and the diagnosis of decay and pathology through the use of analytical and non-destructive techniques were included. The resulted outcome led experts in the completion of a challenging and seemingly impossible restoration of a universal monument, with the result of securing increased number of visitors with the new findings and the safety measures taken $[103,108]$. 
In other parts of the World integrated projects of castles, monasteries of interdisciplinary and multi-scientific nature also were made aiming to increased number of tourists and thus income [109-114].

\section{Discussion}

According to the above, it becomes, by now, easy to perceive that the new technological evolution has dramatically reshaped the value chain, in the way that it impacts the sustainability of the systems of governance for culture. Cultural heritage has a historical, social, and anthropological value and it is considered as an enabler of sustainable development (United Nations' Sustainable Development Goals (SDGs) 11 and 8).

Cultural heritage, on the other hand, contributes significantly to a more balanced and sustainable urban or regional development and economy, providing many opportunities for social interaction and economic growth of host communities. It is, indeed, widely acknowledged that the various aspects and methods of new technology represent a remarkable and valuable tool in terms of economy. Even though the traditional methods of research, assessment, and collection of archaeological data are still being used, sciences and archaeometry come to the aid of professionals in order to assist conservation, archaeology, restoration, and so many others, but also to save time and money. Non-invasive geophysical surveys and remote sensing activities, for example, are nowadays often implemented before the dig in order to provide substantial indications as to the existence of antiquities, a piece of information which would otherwise take long periods of trial trenches to obtain and by sequence large amounts of money and human resources. The documentation of the finds is also easily assured with the use of 3D representations, laser scanning, and several other imaging techniques of high technology. Collections data can be far more detailed and stored in far less space than ever before. Databases can hold complete descriptions along with photographs and links to the raw elements of analysis and interpretation. In addition, the artefact can be compared to previous data to track any changes, such as deterioration or fading. The three-dimensional building models are also increasingly necessary for urban planning within areas including buildings and structures of cultural heritage. In a sense it is perhaps the only though method preserving for the condition of a monument in view of natural and man provoked hazards.

Archaeometry's impact in development applies also to at-risk cultural heritage protection. On the other hand, laboratory tests of high accuracy are also employed against all sorts of fake provenance documentation.

Equally important is that ICT applications making also use of archaeometric results amplify the access of people to cultural information and services, since the public can enjoy them more easily, quickly and cheaply. In terms of economy, ICT provide a great opportunity for cultural industries, especially of tourism and computing, to adopt a sustainable and cultural-social centric approach and to develop into attractive and profitable stakeholders.

The use of archaeometry helps make the cultural heritage industry more widely and effectively extroverted, through the documentation and dissemination of cultural objects, movable and immovable monuments, tangible or intangible heritage, and provides democracy and globalization of the knowledge, participation, and accessibility of local communities and the wider universal community to the local cultural heritage, highlighting regional, territorial sustainable development and cultural tourism.

Archaeometric studies consist of the links between the scientific information derived from cultural sites and objects, museums as cultural transmission areas-either real or virtual-and the global community as the final recipient of cultural data. Digitalization provides new opportunities of data processing and analysis and boost cultural development, including the ability of individuals to have, at any time, no limit of access to cultural heritage.

3D digitization technologies create new promotion potentials of archaeometry and give the European and world public the opportunity to take a close look of the specialized work carried out by 
scientific groups throughout the world, to participate in the fascinating course of science, archaeometry innovative applications, and the experience of cultural documentation.

Virtual world platforms are used for artefacts' and museums' modelling and exposure, while the use of panoramic images is spreading to present captured aspects of a real museum. Many museums, real or fictional, have been created in order to replicate the experience of a physical visit to the museum and make the user feel immersed in the digital space [115].

Sustainable management of the cultural and natural environment aims to the development in an unceasing way. The ultimate goal is the society, science and technology development in such a way as to ensure a durable permanence of future generations (trans-generational) and to reserve in all sectors, mainly environment, but also society and economy, for them [116]. Sustainable development is directly linked to culture and aims at its sustainability. Sustainability as a term links past, present, and future, because people are studying the past and discover those elements that consist of heritage, as perceived at the present time, for the people of the future. As UNESCO states: "Education for Sustainable Development allows every human being to acquire the knowledge, skills, attitudes and values necessary to shape a sustainable future".

With digital archaeological and territorial information interconnected an increase in cultural heritage knowledge worldwide is achieved. Archaeometry data analysis transmission, combined with stakeholders and public involvement, allows a wide participation at the area of cultural management and treatment of monuments and enables individuals' awareness to central decisions about heritage sustainability. Meanwhile, organizations are more careful and responsible about their impact on monuments and cultural environment [18].

The natural and cultural heritage of a region and its management is of particular importance for tourism development, it brings economic benefits but also risks due to the exploitation of sensitive resources such as the natural, cultural, and historical environments. Sustainable management of cultural objects and the soft, controlled development of cultural destinations are required to reduce the negative impact of tourism activity and the consequent economic development. The inclusion of the protection and promotion of cultural goods in the national planning and the local-regional strategy for the sustainable development of the regions is inextricably linked with the development of the economy. The interaction is intense and flows in both directions.

Archaeometrical results coupled with sustainability, and vice versa, as a cause-and-effect relationship benefits several fields; from advancing science, enhancing the value of reminiscent relics, induce a pedagogical effect, provide social cohesion, help economy and employment and reinforce cultural diplomacy. The factors of communication of the archaeometric results to the public, i.e., the manner, media of results communication, the target group that the scientific data is addressing to, the accessibility, influence this relationship. Overall, interdisciplinarity in archaeometry is connected with sustainability because it produces a novel and valuable and unpreceded information on the cultural heritage material. This dual relationship is quantified from statistics of visitors in respective museums or open archaeological sites.

Unhappily the common consensus is not a respected connection between archaeometry and sustainability, as the measurable results are confined to a narrow academia. However, if proper use is made with the results in all fields of archaeometry (provenance, characterization, location, dating, technology, intangible heritage from material culture analysis and interpretation of their arrangement, archaeoastronomy, VR, conservation-restoration, digital documentation, dissemination, etc.) then a direct connection between archaeometry and sustainability will emerge.

Along the lines of archaeometry's role in cultural regional economic sustainability and development strategies, the development of geomythology to decipher ancient myths, emerging from archaeometry applied to intangible heritage is of unprecedented essence. The recent upcoming research discipline of the disaster archaeology and attempts to explain beyond a mythical/legendary account by natural sciences, lead unavoidably to the establishment of a new academic discipline of archaeological mythology, much like biblical archaeology with Israel's patrology conveyed orally 
and finally recorded in the holy Bible [117-119]. Therefore, archaeometry on a perpetually accredited scientifically holistic approach (PASHA) continually and consecutively developed, coupled with the mythologies in the world, the Greek mythology being of paramount importance, adds another dimension in revealing remote past, merging tangible and intangible heritage, and forming a new academic field with social, scientific, and pedagogical dimensions and new learning outcomes.

The systematic way to model the coupling of archaeometry and sustainability needs a combined grounded theory (GT) for quantitative data $[120,121]$, but with traditional comparative ethnography, archaeology, and, if available, ancient literature approach. Archaeometric data are quantitative which are analyzed and treated in such a manner to produce and/or reproduce accurate and precise end product (a date, a content, a reconstruction).

The economic valuation of cultural heritage remains a scientific challenge. Archaeometry's impact targets at the economic effect, either as an external benefit or as a source of tourist attraction. Thus, the application of the contingent valuation method, which has the objective aim to examine the effect of opportunity cost in indirect economic valuation of some special public goods through the supply of voluntary labour may be worth linking to archaeometrical fieldwork [122].

The archaeometry updated by its new technologies may well apply a resilient strategy to cultural heritage, in the domain of fundamental and applied research, education and training, and economy. At any rate the implementation of all these should take into consideration the pertaining uncertainties from natural disasters, terrorist activities, and climatic changes [123].

\section{Conclusions}

Archaeometry is a scientifically-established international discipline that investigates scientific issues of cultural heritage; it is a multidisciplinary science that develops research and solves archaeological problems. With the help of this interdisciplinary subject new unexplored fields, political, cultural, and social landscapes are discovered, and scientific gaps are covered because science, although divided into subgroups, is unified and indivisible.

Archaeometry results consist of data (such as graphs, statistical information, etc.) which simplify and facilitate the possibility of comparing cultural samples and retrieving maximal information from their micro scale, thus conducting safe conclusions, which can be used globally by researchers, scientists, and government officials, resulting in the dissemination of information and the globalization of science, the scientific and administrative dialogue, the promotion of administrative functions, and the convenience of citizens to fair and proper administrative treatment.

Cultural heritage is, without doubt, a particularly complex field. The protection and preservation of archaeological sites, ancient monuments, vernacular architecture, industrial installations, cultural and historical landscapes, and many other forms of cultural property is and should be the object of many disciplines. The integration of cultural management services with archaeometry and information culture technologies has already shown the successful impact in many of the processes of documenting and monitoring, interpreting and communicating the data, enhancing many aspects of the research, building capacity and achieving public involvement in the integration of the past into our lives. The management of big data from archaeometrical applications and the cyber-archaeology in the field, the museum, and the office, upraises the interdisciplinary direction to the PASHA, which has the potential for addressing the new challenges the heritage sector faces and securing its long-term sustainability and preservation, giving a hopeful prosperous future to local, regional, and national economic development, from the cultural heritage re-treatment to economic benefit.

At any rate, combined multi-scientific archaeometric projects, use "new technologies" ("new" in the sense of updated progressive development in science and technology) and retrieve information in the micro- and macroscopic level. The obtained data of applications to current material culture or in the revealing and documentation of new buried antiquities, with proper interpretation and integration in the wider context of tangible and intangible cultural heritage, are inextricably linked to sustainability. 
Author Contributions: Writing: I.L. and E.K.; Providing case and idea: I.L.; Providing revised advice: I.L.

Acknowledgments: Ioannis Liritzis is thankful for the project fund support from Key Research Institute of Yellow River Civilization and Sustainable Development \& Collaborative Innovation Center on Yellow River Civilization of Henan Province, Henan University, Kaifeng 475001, China. Colleagues G.Tsokas and A.Sarris for useful first-hand information on geophysical results, to Niki Platia MSc, for initial useful discussions and N.Laskaris and A.Vafiadou for help in plots.

Conflicts of Interest: The authors declare no conflict of interest.

\section{References}

1. Jones, A. Archaeometry and materiality: Materials-based analysis in theory and practice. Archaeometry 2004, 46, 327-338. [CrossRef]

2. Gilberto, A. Scientific Methods and Cultural Heritage: An Introduction in the Application of Materials Science to Archaeometry and Conservation Science; Oxford University Press: New York, NY, USA, 2010.

3. Schiffer, M.B. Some relationships between behavioural and evolutionary archaeologies. Am. Antiquity 1996, 61, 643-662. [CrossRef]

4. Brown, K.A.; Pluciennik, M. Archaeology and human genetics: Lessons for both. Antiquity 2001, 75, 101-106. [CrossRef]

5. Edmonds, M. Science, technology and society. Scott. Archaeol. Rev. 1990, 7, 23-31.

6. Dunnell, R.C. Why archaeologists don't care about archaeometry. Archeomaterials 1993, 7, 161-165.

7. Liritzis, I. The contribution of archaeometry to the development (cultural, economic) of the Mediterranean islands. J. Mediterr. Stud. 2001, 10, 225-2308.

8. Liritzis, I. Does Archaeometry contribute in the development of cultural educational tourism \& sustainable development? In Proceedings of the 17th Scientific Conference of Greek Regionalists Delphi “The Future of Develomental and Urban Planning of Greece", Athens, Greece, 2012; pp. 545-559. (In Greek)

9. Liritzis, I. Searching for buried relics in the Castle of Salona (Greece) with geophysical methods: Examples and proposal. In Proceedings of the 1st Conference on "Castle of Salona (Amfissa): Historical Prospectives, Possibilities E Cultural Development", 2013; Papakonstantinou, M., Ed.; Municipality of Delphi in Collaboration with 24th Ephoria of Byzantine Antiquities \& 8th Ephoria of Classical-Prehistoric Antiquities: Lamia, Greece, 2013. (In Greek)

10. Psycharis, S. STEAM in education: A literature review on the role of computational thinking, engineering epistemology and computational science. computational steam pedagogy (CSP). Sci. Cult. 2018, 4, 51-72. [CrossRef]

11. Panou, E.; Violetis, A. Teaching astronomy using monuments of cultural heritage: The educational example of "Horologion of Andronikos Kyrrhestes". Sci. Cult. 2018, 4, 77-83. [CrossRef]

12. Liritzis, I. STEMAC (Science, Technology, Engineering, Mathematics for Arts \& Culture): The emergence of a new pedagogical discipline. Sci. Cult. 2018, 4, 73-76. [CrossRef]

13. Anderson, C.; Törnberg, A.; Törnberg, P. An Evolutionary Developmental Approach to Cultural Evolution. Curr. Anthropol. 2014, 55, 154-174. [CrossRef]

14. Liritzis, I. Twelve thousand years of non-linear cultural evolution: The physics of chaos in Archaeology. Synesis J. Sci. Technol. Ethics Policy 2013, 4, G19-G31.

15. Kintigh, K.; Altschul, J.; Beaudry, M.; Drennan, R.; Kinzig, A.; Kohler, T.; Limp, W.F.; Maschner, H.; Michener, W.; Pauketat, T.; et al. Grand Challenges for Archaeology. Am. Antiquity 2014, 79, 5-24. [CrossRef]

16. Thomas, B.; Thomas, S.; Powell, L. The development of key characteristics of welsh island cultural identity and sustainable tourism in Wales. Sci. Cult. 2017, 3, 23-39. [CrossRef]

17. El-Menshawy, S. Traveling within pharaonic Egypt for discovering the past. Sci. Cult. 2017, 3, 15-21. [CrossRef]

18. Liritzis, I.; Al-Otaibi, F.M.; Volonakis, P.; Drivaliari, A. Digital technologies and trends in cultural heritage. Mediterr. Archaeol. Archaeom. 2015, 15, 313-332. [CrossRef]

19. Reindel, M.; Wagner, G.A. New Technologies for Archaeology, Multidisciplinary Investigations in Palpa and Nasca, Peru; Springer Science \& Business Media: Berlin/Heidelberg, Germany, 2009; p. 2.

20. Available online: www.icomos.org (accessed on 18 March 2019).

21. Edwards, H.; Vandenabeele, P. Analytical Archaeometry, Selected Topics; RSC Publishing: Cambridge, UK, 2012. 
22. Li, F. VR Cultural Heritage Sites: A Case Study on Creating Immersive Visual \& Auditory Experience. BSc Senior Thesis, Rose-Hulman Institute of Technology, Department of Computer Science and Software Engineering, Terre Haute, IN, USA, 2016.

23. Kanellos, I.; Antin, S.; Dimou, O.; Kanellos, M.-A. Educational enhancing of virtual expositions. towards visitor-centered storytelling digital museology. Mediterr. Archaeol. Archaeom. 2014, 14, 117-123.

24. Sarris, A. (Ed.) Best Practices of GeoInformatic Technologies for the Mapping of Archaeolandscapes. Archaeopress Archaeology; Archaeopress Publishing Ltd.: Oxford, UK, 2015; ISBN 9781784911621.

25. Liritzis, I.; Zacharias, N.; Papageorgiou, I.; Tsaroucha, A.; Palamara, E. Characterisation and analyses of museum objects using pXRF: An application from the Delphi Museum, Greece. Stud. Antiqua Archaeol. 2018, 24, 31-50.

26. Levy, T.E.; Sideris, T.; Howland, M.; Liss, B.; Tsokas, G.; Stambolidis, A.; Fikos, E.; Vargemezis, G.; Tsourlos, P.; Georgopoulos, A.; et al. At-Risk World Heritage, Cyber, and Marine Archaeology: The Kastrouli-Antikyra Bay and Sea Project, Phokis, Greece. In Cyber-Archaeology and Grand Narratives, One World Archaeology; Levy, T.E., Jones, I.W.N., Eds.; Springer International Publishing AG: Basel, Switzerland, 2018; pp. 143-230.

27. Sarris, A.; Déderix, S. GIS for Archaeology and Cultural Heritage Management in Greece. Quo Vadis? In Proceedings of the 3rd Symposium Archaeological Research and New Technologies ARCH_RNT, Kalamata, Greece, 3-6 October 2012; pp. 7-20.

28. Portalés, C.; Alonso-Monasterio, P.; Viñals, M.J. 3D virtual reconstruction and visualisation of the archaeological site Castellet de Bernabé (Llíria, Spain). Virtual Archaeol. Rev. 2017, 8, 75-82. [CrossRef]

29. Balla, A.; Pavlogeorgatos, G.; Tsiafakis, D.; Pavlidis, D. Recent advances in archaeological predictive modeling for archeological research and cultural heritage management. Mediterr. Archaeol. Archaeom. 2014, 14, 143-153.

30. Hatzopoulos, J.N.; Stefanakis, D.; Georgopoulos, A.; Tapinaki, S.; Volonakis, S.; Volonakis, P.; Liritzis, I. Use of various surveying technologies to $3 \mathrm{D}$ digital mapping and modelling of cultural heritage structures for maintenance and restoration purposes: The Tholos in Delphi, Greece. Mediterr. Archaeol. Archaeom. 2017, 17, 311-336. [CrossRef]

31. Zara, J. Virtual Reality and Cultural Heritage on the Web. In Proceedings of the 7th International Conference on Computer Graphics and Artificial Intelligence (3IA 2004), Limoges, France, 12-13 May 2004; pp. 101-112.

32. Georgopoulos, A. 3D virtual reconstruction of archaeological monuments. Mediterr. Archaeol. Archaeom. 2014, 14, 155-164.

33. Barsanti, S.G.; Caruso, G.; Micoli, L.L.; Rodriguez, M.C.; Guidi, G. 3D visualization of cultural heritage artefacts with virtual reality devices. Int. Arch. Photogramm. Remote Sens. Spat. Inf. Sci. 2015, XL-5/W7, 165-172. [CrossRef]

34. Bruno, F.; Lagudi, A.; Barbieri, L. Virtual Reality Technologies for the Exploitation of Underwater Cultural Heritage. In Latest Developments in Reality-Based 3D Surveying and Modelling; Remondino, F., Georgopoulos, A., González-Aguilera, D., Agrafiotis, P., Eds.; MDPI: Basel, Switzerland, 2018; pp. 220-236.

35. Osburg, T.; Lohrmann, C. Sustainability in a Digital World. New Opportunities Through New Technologies; Springer: Cham, Switzerland, 2017.

36. Sarris, A.; Papadopoulos, N.; Agapiou, A.; Salvi, M.C.; Hadjimitsis, D.; Parkinson, W.; Yerkes, R.; Gyucha, A.; Duffy, P. Integration of geophysical surveys, ground hyperspectral measurements, aerial and satellite imagery for archaeological prospection of prehistoric sites: The case study of Vésztő-Mágor Tell, Hungary. J. Archaeol. Sci. 2013, 40, 1454-1470. [CrossRef]

37. Tsokas, G.N.; Giannopoulos, A.; Tsourlos, P.; Vargemezis, G.; Tealby, J.M.; Sarris, A.; Papazachos, C.B.; Savopoulou, T. A large-scale geophysical survey in the archaeological site of Europos (nothern Greece). J. Appl. Geophys. 1994, 32, 85-98. [CrossRef]

38. Pavlidis, G.; Levy, T.; Liritzis, I. Pedagogy and Engagement in At-Risk World Heritage Initiatives. In Heritage and Archaeology in the Digital Age: Acquisition, Curation, and Dissemination of Spatial Cultural Heritage Data; Vincent, M.L., Bendicho, V.M., Ioannides, M., Levy, T.E., Eds.; Springer International Publishing: Basel, Switzerland, 2018; pp. 167-183.

39. Tsiafaki, D.; Michailidou, N. Benefits and problems through the application of $3 \mathrm{~d}$ technologies in archaeology: Recording, visualisation, representation and reconstruction. Sci. Cult. 2015, 1, 37-45. [CrossRef]

40. Liritzis, I.; Polychroniadou, E. Optical and analytical techniques applied to the Amfissa Cathedral mural paintings made by the Greek artist Spyros Papaloukas (1892-1957). Revue d'Archaeometrie (Archaeosciences) 2007, 31, 97-112. 
41. Pratt, C.E. Critical Commodities: Tracing Greek Trade in Oil and Wine from the Late Bronze Age to the Archaic Period. Ph.D. Thesis, California Digital Library, University of California, Los Angeles, CA, USA, 2014.

42. Elhagrassy, A.F.; Hakeem, A. Comparative study of biological cleaning and laser techniques for conservation of weathered stone in Failaka island, Kuwait. Sci. Cult. 2018, 4, 43-50. [CrossRef]

43. Abdel Rahim, N.S. Analytical study and conservation of archaeological terra sigıllata ware from roman period, Tripoli, Libya. Sci. Cult. 2016, 2, 19-27. [CrossRef]

44. Kousouni, C.-K.; Panagopoulou, A. Non-destructive physicochemical analysis and conservation of metallic book covers of ecclesiastical books from Saint Mavra and Timotheos Church in Zakynthos (Greece). Sci. Cult. 2018, 4, 85-95. [CrossRef]

45. Scollar, I.; Tabbach, A.; Hesse, A.; Herzog, I. Archaeological Prospecting and Remote Sensing; Cambridge University Press: Cambridge, UK, 1990.

46. Athanasiou, E.; Tsourlos, P.I.; Vargemezis, G.; Papazachos, C.B.; Tsokas, G.N. Nondestructive DC resistivity surveying using flat-base electrodes. Near Surf. Geophys. 2007, 5, 243-272. [CrossRef]

47. Angelis, D.; Tsourlos, P.; Tsokas, G.; Vargemezis, G.; Zacharopoulou, G.; Power, C. Combined application of GPR and ERT for the assessment of a wall structure at the Heptapyrgion fortress (Thessaloniki, Greece). J. Appl. Geophys. 2018, 152, 208-220. [CrossRef]

48. Drahor, M.G.; Tsokas, G.N.; Piro, S.; Trinks, I. Integrated Geopysical Investigations for Archaeology Foreword. Near Surf. Geophys. 2015, 13, 519-521. [CrossRef]

49. Lasaponara, R.; Masini, N. Detection of archaeological crop marks by using satellite QuickBird multispectral 477 imagery. J. Archaeol. Sci. 2007, 34, 214-221. [CrossRef]

50. Karamitrou, A.; Petrou, M.; Tsokas, G.N. A pixel-based semi-stochastic algorithm for the registration of 479 geophysical images. Archaeol. Prospect. 2017, 24, 413-424. [CrossRef]

51. Geophysics Techniques. Available online: http://www.bsr.ac.uk/research/archaeology/geophysics-2/ geophysics-techniques (accessed on 18 March 2019).

52. El-Qady, G.; Metwaly, M. (Eds.) Archaeogeophysics: State of the Art and Case Studies; Springer Nature: Cham, Switzerland, 2019.

53. Sarris, A.; Kalayci, T.; Papadopoulos, N. Geophysical Prospection on the Volcanic Environs of Therasia Island, Cyclades, Greece. ISAP NEWS 2013, 37, 2-4.

54. Sarris, A.; Topouzi, S.; Adrimi-Sismani, V. Mycenaean Dimini: Integration of Geophysical Surveying and GIS. In Proceedings of the CAA2002 International Conference: Computer Applications \& Quantitative Methods in Archaeology, The Digital Heritage of Archaeology, Herakleion, Crete, Greece, 2-6 April 2002; pp. 1-6.

55. Papadopoulos, N.G.; Sarris, A.; Kokkinou, E.; Wells, B.; Penttinen, A.; Savini, E.; Tsokas, G.N.; Tsourlos, P. Contribution of multiplexed electrical resistance and magnetic techniques to the archaeological investigations at Poros, Greece. J. Archaeol. Prospect. 2006, 13, 75-90. [CrossRef]

56. Pentinnen, A.; Wells, B.; Mylona, D.; Pakkanen, P.; Pakkanen, J.; Karivieri, A.; Hoorton, A.; Savini, E.; Theodoropoulou, T. Report on the Excavations in the Years 2007 and 2008 Southeast of the Temple of Poseidon at Kalaureia. Opuscula 2009, 2, 89-141. [CrossRef]

57. Sarris, A.; Papadopoulos, N.; Trigkas, V.; Kokkinou, E.; Alexakis, D.; Kakoulaki, G.; De Marco, E.; Seferou, E.; Shen, G.; Karaoulis, M.; et al. Recovering the Urban Network of Ancient Sikyon through Multi-component geophysical approaches. In Layers of Perception, Proceedings of the 35th International Conference on Computer Applications and Quantitative Methods in Archaeology (CAA), Berlin, Germany, 2-6 April 2007; Posluschn, A., Lambers, K., Herzog, I., Eds.; Kolloquien zur Vor und Frühgeschichte: Bonn, Germany, 2007; Volume 10, pp. 11-16.

58. Sarris, A.; Papadopoulos, N. Geophysical Surveying in Urban Centers of Greece. In Proceedings of the 16th International Congress "Cultural Heritage and New Technologies", Vienna, Austria, 14-16 November 2011; pp. 96-114, ISBN 978-3-200-02740-4.

59. Sarris, A.; Manataki, M.; Dederix, S. Geophysical Investigations at Sissi 2015-2016. In AEGIS 13: Excavations at Sissi IV. Preliminary Report on the 2015-2016 Campaigns; Driessen, J., Anastasiadou, M., Caloi, I., Claeys, T., Déderix, S., Devolder, M., Jusseret, S., Langohr, C., Letesson, Q., Mathioudaki, I., et al., Eds.; Presses universitaires de Louvain: Louvain-la-Neuve, Belgium, 2018; pp. 43-58. 
60. Vanek, D.; Brzobohata, H.; Silerova, M.; Horak, Z.; Nyvltova Fisakova, V.G.; Vasinova Galiova, M.; Zednikova Mala, P.; Urbanova, V.; Dobisikova, M.; Beran, M.; et al. Complex Analysis of 700-Year-Old Skeletal Remains found in an Unusual Grave-Case Report. Anthropol 2015, 2. [CrossRef]

61. Cooper, A.; Green, C. Embracing the Complexities of 'Big Data' in Archaeology: The Case of the English Landscape and Identities Project. J. Archaeol. Method Theory 2016, 23, 271-304.

62. Moscati, P. (Ed.) Virtual Museums and Archaeology. The Contribution of the Italian National Research Council; Archeologia E Calcolatori, Supplemento 1; Publ. All'Insegna del Giglio: Roma, Italy, 2007.

63. Barcelo, J.A.; Moitinho de Almeida, V. Functional analysis from visual and non-visual data an arti-ficial intelligence approach. Mediterr. Archaeol. Archaeom. 2012, 12, 273-321.

64. Forte, M. Cyber-Archaeology; Archaeopress: Oxford, UK, 2010.

65. Levy, T.E.; Petrovic, V.; Wypych, T.; Gidding, A.; Knabb, K.; Hernandez, D.; Smith, N.; Schlulz, J.; Savage, S.; Kuester, F.; et al. On-Site Digital Archaeology 3.0 and Cyber-Archaeology: Into the Future of the Past-New Developments, Delivery and the Creation of a Data Avalanche. In Cyber Archaeology; Forte, M., Ed.; BAR International Series 2177; Archaeopress: Oxford, UK, 2010; pp. 135-153.

66. Siebke, I.; Campana, L.; Ramstein, M.; Furtwängler, A.; Hafner, A.; Lösch, A. The application of different 3D-scan-systems and photogrammetry at an excavation-A Neolithic dolmen from Switzerland. Digit. Appl. Archaeol. Cult. Herit. 2018, 10, e00078. [CrossRef]

67. Williams, H.; Atkin, A. Virtually Dead: Digital Public Mortuary Archaeology. Internet Archaeol. $2015,40$. [CrossRef]

68. Proctor, N. Digital: Museum as Platform, Curator as Champion, in the Age of Social Media. Curator. Mus. J. 2010, 53, 35-43. [CrossRef]

69. Ulguim, P. Models and Metadata: The Ethics of Sharing Bioarchaeological 3D Models Online. Archaeologies 2018, 14, 189-228. [CrossRef]

70. The Inscriptions of the Antikythera Mechanism. Almagest (J. Netw. Hist. Sci. South. Eur.) 2016, 7, 6-310, (volume dedicated to Antikythera mechanism). [CrossRef]

71. Available online: https://www.bibliotecapleyades.net/ciencia/esp_ciencia_antikythera02.htm (accessed on 18 March 2019).

72. Available online: https://www.bibliotecapleyades.net/ciencia/esp_ciencia_antikythera07.htm (accessed on 18 March 2019).

73. Seiradakis, J.H.; Edmunds, M.G. Our current knowledge of the Antikythera Mechanism. Nat. Astron. 2018, 2, 35-42. [CrossRef]

74. Freeth, T. The Antikythera mechanism I: Challenging the classic research. Mediterr. Archaeol. Archaeom. 2002, 2, 21-35.

75. Available online: http://www.antikythera-mechanism.gr/project/overview (accessed on 18 March 2019).

76. Freeth, T. The Antikythera mechanism. II: Is Posidoniu's Orrery? Mediterr. Archaeol. Archaeom. 2002, 2, 45-58.

77. Bonani, G.; Ivy, S.; Hajdas, I.; Niklaus, T.R.; Suter, M. AMS 14C age determinations of tissue, bone and grass samples from the Ötztal Ice Man. Radiocarbon 1994, 36, 247-250. [CrossRef]

78. Kutschera, W.; Rom, W. Ötzi, the prehistoric Iceman. Nucl. Instrum. Methods Phys. Res. Sect. B Beam Interact. Mater. Atoms 2000, 164-165, 12-22. [CrossRef]

79. Artioli, G.; Angelini, I.; Kaufmann, G.; Canovaro, C.; Dal Sasso, G.; Villa, I.M. Correction: Long-distance connections in the Copper Age: New evidence from the Alpine Iceman's copper axe. PLoS ONE 2017, 12, e0189561. [CrossRef]

80. Macko, S.A.; Lubec, G.; Teschler-Nicola, M.; Andrusevich, V.; Engel, M.H. The Ice Man's diet as reflected by the stable nitrogen and carbon isotopic composition of his hair. FASEB J. 1999, 13, 559-562. [CrossRef] [PubMed]

81. Price, D.T.; Burton, J.H. An Introduction to Archaeological Chemistry; Springer: New York, NY, USA, 2012.

82. O'Sullivan, N.J.; Teasdale, M.D.; Mattiangeli, V.; Maixner, F.; Pinhasi, R.; Bradley, D.G.; Zink, A. A whole mitochondria analysis of the Tyrolean Iceman's leather provides insights into the animal sources of Copper Age clothing. Sci. Rep. 2016, 6, 31279. [CrossRef]

83. Kutschera, W.; Muller, W. "Isotope language" of the Alpine Iceman investigated with AMS and MS. Nucl. Instrum. Methods Phys. Res. B 2003, 204, 705-719. [CrossRef]

84. Müller, W.; Fricke, H.; Halliday, A.N.; McCulloch, M.T.; Wartho, J.A. Origin and Migration of the Alpine Iceman. Science 2003, 302, 862-866. [CrossRef] 
85. Rollo, F.; Ubaldi, M.; Ermini, L.; Marota, I. Ötzi's last meals: DNA analysis of the intestinal content of the Neolithic glacier mummy from the Alps. Proc. Natl. Acad. Sci. USA 2002, 99, 12594-12599. [CrossRef] [PubMed]

86. Bortemschlager, S.; Oeggl, K. (Eds.) The Iceman and His Natural Environment Palaeobotanical Results; Springer: Wien, Austria, 2000.

87. Available online: https://www.livescience.com/13150-otzi-reconstruction-iceman-mummy-copper-age. html (accessed on 18 March 2019).

88. Available online: http://www.iceman.it/en/5-mio-visitors/ (accessed on 18 March 2019).

89. Available online: https://www3.astronomicalheritage.net/ (accessed on 18 March 2019).

90. Brida, J.G.; Meleddu, M.; Pulina, M. Museum Visitors Can Be Regarded as Specific Cultural Tourists? A Length of Stay Analysis; Working Papers; CREN O S: Cagliari, Italy, 2011; Volume 14.

91. Available online: http://baron-de-synclair.blogspot.com/2012/06/cette-carte-est-elle-representative.html (accessed on 18 March 2019).

92. Available online: https://www.english-heritage.org.uk/visit/places/stonehenge/history-and-stories/ stonehenge360/ (accessed on 18 March 2019).

93. Stukeley, W. Stonehenge, A Temple Restor'd to the British Druids; W. Innys \& R Manby: London, UK, $1740 ;$ p. 81.

94. Hawkins, G.S. Stonehenge Decoded; Souvenir Press: London, UK, 1966.

95. Thom, A.; Stevenson, T.A.; Strang, T.A. Stonehenge. J. Hist. Astron. 1974, 5, 71-90. [CrossRef]

96. Hill, R. Stonehenge; Profile Books: London, UK, 2008.

97. Ruggles, C.; Hoskin, M. Astronomy Before History. I: The Cambridge Concise History of Astronomy; Michael, H., Ed.; Cambridge University Press: Cambridge, MA, USA, 1999; p. 6.

98. Thom, A.; Stevenson, T.A.; Strang, T.A. Stonehenge as a Possible Lunar Observatory. J. Hist. Astron. 1975, 6, 19-30. [CrossRef]

99. Available online: https://www.statista.com/statistics/586843/stonehenge-visitor-numbers-unitedkingdom-uk/ (accessed on 18 March 2019).

100. Unver, E.; Taylor, A. Virtual Stonehenge Reconstruction. In Progress in Cultural Heritage Preservation; Ioannides, M., et al., Eds.; Springer-Verlag: Berlin/Heidelberg, Germany, 2012; pp. 449-460.

101. MacDonald, J. New media applications and their potential for the advancement of public perceptions of archaeoastronomy and for the testing of archaeoastronomical hypotheses. Mediterr. Archaeol. Archaeom. 2006, $6,181-184$.

102. Bayliss, A.; Bronk Ramsey, C.; McCormac, F.G. Dating Stonehenge. Proc. Br. Acad. 1997, 92, 39-59.

103. Available online: https://www.researchgate.net/publication/323128412_FAITHFUL_REHABILITATION_ OF_THE_HOLY_TOMB_OF_CHRIST/references (accessed on 18 March 2019).

104. Masini, N.; Capozzoli, L.; Chen, P.; Chen, F.; Romano, G.; Lu, P.; Tang, P.; Sileo, M.; Ge, Q.; Lasaponara, R. Towards an Operational Use of Geophysics for Archaeology in Henan (China): Methodological Approach and Results in Kaifeng. Remote Sens. 2017, 9, 809. [CrossRef]

105. Ge, Q. Report of Archaeological Stratigraphy; Kaifeng Institute of Archaeology CASS: Kaifeng, China, 2016.

106. Neville, A.; Bridgland, J. (Eds.) Of the Past, for the Future: Integrating Archaeology and Conservation, Proceedings of the Conservation Theme at the 5th World Archaeological Congress, Washington, DC, USA, 22-26 June 2003; Getty Conservation Institute Symposium Proceedings Series; Getty Conservation Institute: Los Angeles, CA, USA, 2006; Available online: http:/ /hdl.handle.net/10020/gci_pubs/of_past_for_future (accessed on 18 March 2019).

107. Patsavos, N.; Mergos, G. Cultural Heritage and Sustainable Development. Economic Benefits, Social Opportunities, Policy Challenges; Technological University of Crete, and InHerit Erasmus+: Crete, Greece, 2017.

108. Moropoulou, A.; Zacharias, N.; Delegou, E.T.; Apostolopoulou, M.; Palamara, E.; Kolaiti, A. OSL mortar dating to elucidate the construction history of the Tomb Chamber of the Holy Aedicule of the Holy Sepulchre in Jerusalem. J. Archaeol. Sci. Rep. 2018, 19, 80-91. Available online: https:/ /www.int-arch-photogrammremote-sens-spatial-inf-sci.net/XLII-5-W1/487/2017/isprs-archives-XLII-5-W1-487-2017.pdf (accessed on 18 March 2019). [CrossRef]

109. Elyamani, A. Re-use proposals and structural analysis of historical palaces in Egypt: The case of Baron Empain Palace in Cairo. Sci. Cult. 2018, 4, 53-73. [CrossRef]

110. Salama, K.K.; Ali, M.F.; Moussa, A.M. Deterioration factors facing mural paintings in el Sakakeny Palace (problems and solutions). Sci. Cult. 2016, 2, 5-9. [CrossRef] 
111. Amin, E.A. Technical investigation and conservation of a tapestry textile from the Egyptian textile Museum, Cairo. Sci. Cult. 2018, 4, 35-46. [CrossRef]

112. Elyamani, A.; Roca, P. One century of studies for the preservation of one of the largest cathedrals worldwide: A Review. Sci. Cult. 2018, 4, 1-24. [CrossRef]

113. Măruţoiu, C.; Bratu, I.; Troşan, L.; Neamtu, C.; Măruţoiu, V.C.; Pop, D.; Tănăselia, C.; Garabagiu, S. Scientific Investigation of the Imperial Gates Belonging to the 17th Century Wooden Church of Sălișca, Cluj County, Romania. Sustainability 2018, 10, 1503. [CrossRef]

114. Elyamani, A.; Roca, P. A review on the study of historical structures using integrated investigation activities for seismic safety assessment. Part II: Model updating and seismic analysis. Sci. Cult. 2018, 4, $29-51$. [CrossRef]

115. Vosinakis, S.; Tsakonas, Y. Visitor experience in google art project and in second life-based virtual museums: A comparative study. Mediterr. Archaeol. Archaeom. 2016, 16, 19-27. [CrossRef]

116. Krysiak, F.; Krysiak, D. Sustainability with Uncertain Future Preferences, Environmental \& Resource Economics. Eur. Assoc. Environ. Resour. Econ. 2006, 33, 511-531.

117. Vitaliano, D.B. Geomythology: Geological Origins of Myths and Legends. In Myth and Geology; Piccardi, L., Masse, W.B., Eds.; GSL, Special Publications: London, UK, 2007; Volume 273, pp. 1-7.

118. Levy, T.E.; Schnider, T.; Propp, W. (Eds.) Israel's Exodus in Transdisciplinary Perspective; Springer: Berlin, Germany, 2015.

119. Liritzis, I.; Raftopoulou, M. Argolid: Connection of Prehistoric Legends with Geoenvironmental and Archaeological Evidence; TUBA-AR, II; Turkish Academy of Sciences: Ankara, Turkey, 1999; pp. 87-99.

120. Glaser, B.G.; Strauss, A. Discovery of Grounded Theory. Strategies for Qualitative Research; Aldine Transaction: London, UK, 1967.

121. Corbin, J.; Strauss, A. Basics of Qualitative Research: Techniques and Procedures for Developing Grounded Theory, 3rd ed.; Sage Publications, Inc.: Thousand Oaks, CA, USA, 2008.

122. Kopsidas, O. The Opportunity Cost as a Critical Determinant Factor of the Cultural Heritage Monuments' Valuation: A Modified Contingent Valuation Method. J. Environ. Sci. Eng. B 2018, 7, 55-64. [CrossRef]

123. Macalister, F. Preparing for the future: Mitigating disasters and building resilience in the cultural heritage sector. J. Inst. Conserv. 2015, 38, 115-129. [CrossRef] 